\title{
Waveband specific transcriptional control of select genetic pathways in vertebrate skin (Xiphophorus maculatus)
}

Ronald B. Walter, Mikki Boswell, Jordan Chang, William T. Boswell, Yuan Lu, Kaela Navarro, Sean M. Walter, Dylan J. Walter, Raquel Salinas and Markita Savage

\begin{abstract}
Background: Evolution occurred exclusively under the full spectrum of sunlight. Conscription of narrow regions of the solar spectrum by specific photoreceptors suggests a common strategy for regulation of genetic pathways. Fluorescent light (FL) does not possess the complexity of the solar spectrum and has only been in service for about 60 years. If vertebrates evolved specific genetic responses regulated by light wavelengths representing the entire solar spectrum, there may be genetic consequences to reducing the spectral complexity of light.

Results: We utilized RNA-Seq to assess changes in the transcriptional profiles of Xiphophorus maculatus skin after exposure to FL ("cool white"), or narrow wavelength regions of light between 350 and $600 \mathrm{~nm}$ (i.e., $50 \mathrm{~nm}$ or $10 \mathrm{~nm}$ regions, herein termed "wavebands"). Exposure to each $50 \mathrm{~nm}$ waveband identified sets of genes representing discrete pathways that showed waveband specific transcriptional modulation. For example, 350-400 or 450-500 nm waveband exposures resulted in opposite regulation of gene sets marking necrosis and apoptosis (i.e., 350-400 nm; necrosis suppression, apoptosis activation, while 450-500 nm; apoptosis suppression, necrosis activation).

Further investigation of specific transcriptional modulation employing successive $10 \mathrm{~nm}$ waveband exposures between 500 and $550 \mathrm{~nm}$ showed; (a) greater numbers of genes may be transcriptionally modulated after $10 \mathrm{~nm}$ exposures, than observed for $50 \mathrm{~nm}$ or $\mathrm{FL}$ exposures, (b) the $10 \mathrm{~nm}$ wavebands induced gene sets showing greater functional specificity than $50 \mathrm{~nm}$ or $\mathrm{FL}$ exposures, and (c) the genetic effects of $\mathrm{FL}$ are primarily due to $30 \mathrm{~nm}$ between 500 and $530 \mathrm{~nm}$.

Interestingly, many genetic pathways exhibited completely opposite transcriptional effects after different waveband exposures. For example, the epidermal growth factor (EGF) pathway exhibits transcriptional suppression after FL exposure, becomes highly active after 450-500 nm waveband exposure, and again, exhibits strong transcriptional suppression after exposure to the 520-530 nm waveband.
\end{abstract}

Conclusions: Collectively, these results suggest one may manipulate transcription of specific genetic pathways in skin by exposure of the intact animal to specific wavebands of light. In addition, we identify genes transcriptionally modulated in a predictable manner by specific waveband exposures. Such genes, and their regulatory elements, may represent valuable tools for genetic engineering and gene therapy protocols.

Keywords: Southern Platyfish, Light source, Wavelength, RNA-Seq, Differential gene expression, Skin, Transcriptional regulation

\footnotetext{
* Correspondence: RWalter@txstate.edu

The Xiphophorus Genetic Stock Center, Molecular Biosciences Research

Group, Department of Chemistry and Biochemistry, Texas State University,

419 Centennial Hall, 601 University Drive, San Marcos, TX 78666, USA
}

(c) The Author(s). 2018 Open Access This article is distributed under the terms of the Creative Commons Attribution 4.0 International License (http://creativecommons.org/licenses/by/4.0/), which permits unrestricted use, distribution, and reproduction in any medium, provided you give appropriate credit to the original author(s) and the source, provide a link to the Creative Commons license, and indicate if changes were made. The Creative Commons Public Domain Dedication waiver (http://creativecommons.org/publicdomain/zero/1.0/) applies to the data made available in this article, unless otherwise stated. 


\section{Background}

The perception of light by specialized retinal cells and the mechanism by which this leads to an organismal response are topics that have been well studied [1-3]. The genetics and evolution of photoreceptors have also been subjects of strong interest [4, 5], and recent genome level analyses have forwarded new insights into the array of potential photoreceptors in both terrestrial and aquatic vertebrates [6, 7].

Groundbreaking studies by many investigators over the past few decades have given us a reasonable understanding of light reception in the eye, and transduction of the light energy into a neural impulse. In the human eye, light signals are received from an estimated $\approx 130$ million rods and cones. Collectively, these light signals are processed in the brain where the light information is transduced to the organs inciting appropriate genetic responses that have been selected for over evolutionary history $[8,9]$. An inherent aspect of the molecular complexity of photoreception, from a genetic perspective, is the necessity for an appropriate genetic response to light to be based on the collective nature of the light normally received in any particular niche during the evolution of vertebrate species.

Fishes have long-served as valuable vertebrate models to study light reception, and it has been well-established that fishes possess non-visual photosensitive receptors in the pineal gland, brain and skin [9-11]. Indeed, fish organs dissected and exposed to light outside the animal show light responsive expression in gene sets involved with circadian cycling [12], and further, that reentrainment of circadian clock gene expression can be induced in a wide array of zebrafish organs (i.e., brain, eye, fin, gill, gut, heart, liver, muscle, pineal, pituitary, skin, testis) after removal from the organism [6]. These findings, and others, suggest non-visual photoreception may be broadly expressed and active in many organ types.

Evolution occurred over 3 billion years exclusively under the full spectrum of sunlight (Fig. 1). Thus, all spectral wavebands were represented during vertebrate evolution; however, due to specific niche physical

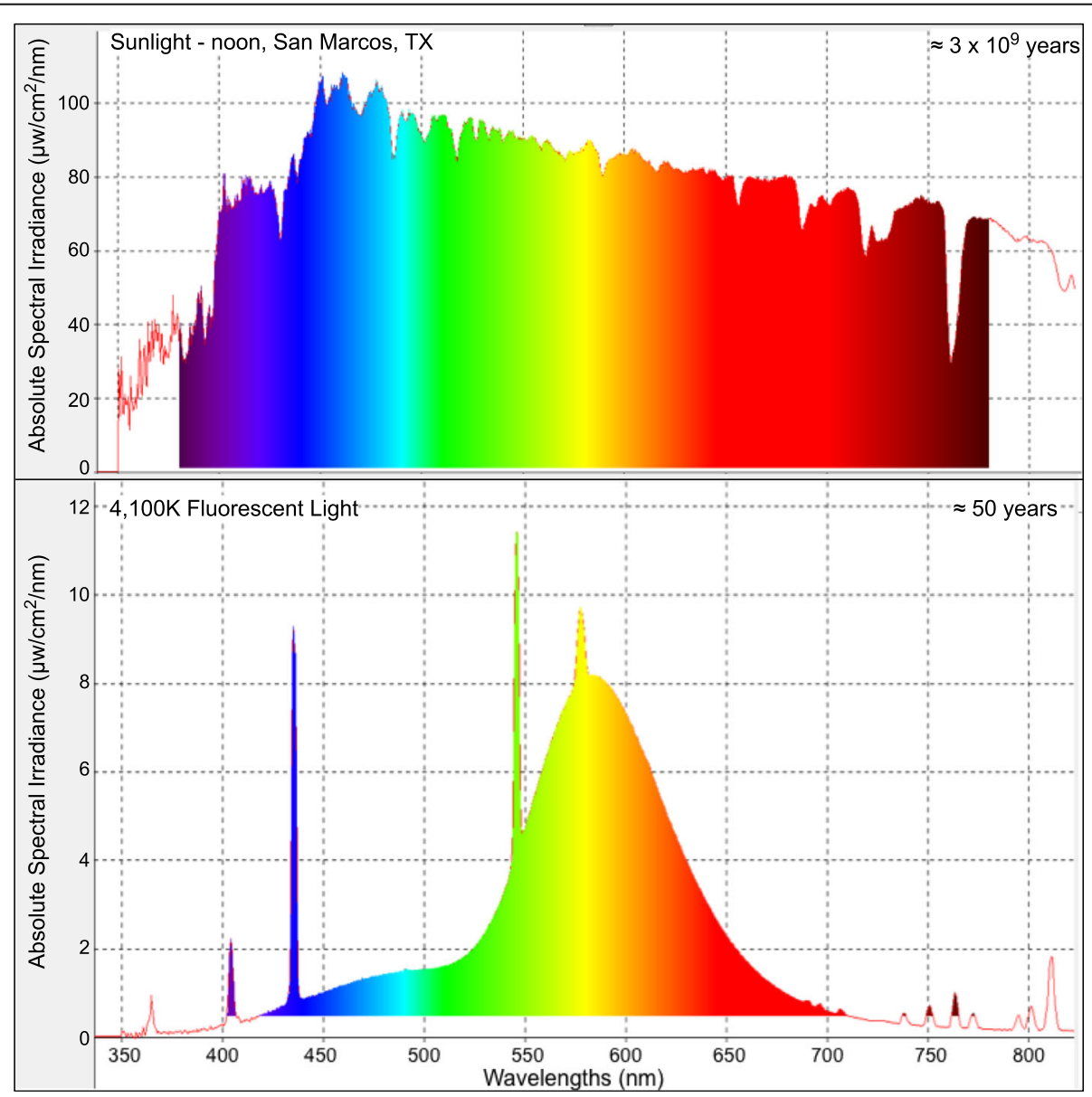

Fig. 1 Complex spectra for sunlight (top) measured at noon in San Marcos, TX, and $4100 \mathrm{~K} \mathrm{FL} \mathrm{(bottom).} \mathrm{Middle} \mathrm{(green} \mathrm{peak)} \mathrm{is} 550 \mathrm{~nm}$ and increments are $50 \mathrm{~nm}$ 
pressures, organisms may have adaptively paired select genetic responses with different spectral regions (wavebands) and/or light intensities. In contrast to the solar spectrum, fluorescent light (FL) has only been in service for about 60 years and these light sources do not fully represent the solar spectrum (Fig. 1). If vertebrates evolved specific genetic responses that utilize select light wavebands within the solar spectrum, there may be genetic consequences to substantially reducing the spectral complexity of light.

In the wild, as cold-blooded vertebrates, fishes utilize light for warmth, predation, predator avoidance, coordination of diurnal metabolic activity, and as cues for monthly or yearly breeding cycles. Functional genomic analyses have shown existence of new and varied candidate photoreceptor genes in zebrafish [6] involving 42 new opsin genes that may produce 10 known visual and 32 non-visual opsins. These new genes hallmark four new opsin classes that seem to have arisen in zebrafish, possibly proceeding the teleost specific genome duplication $[6,13,14]$. The teleost specific genome duplication allowed each fish group to independently retain and alter new sets of visual and non-visual photoreceptor genes and thus, to receive and process light in new ways dependent on adaptation to their specific niche. However, the varied molecular genetic responses that may occur among fishes, after the intact organism is exposed to specific narrow wavelength regions (i.e., wavebands) of light has not been extensively investigated.

To begin to address the question of light waveband induced genetic response, we have recently employed tractable fish models such as the live-bearing tropical fish, Xiphophorus (Fig. 2), to perform experiments detailing modulation of gene expression patterns in skin and other organs after exposure of the intact animal to various

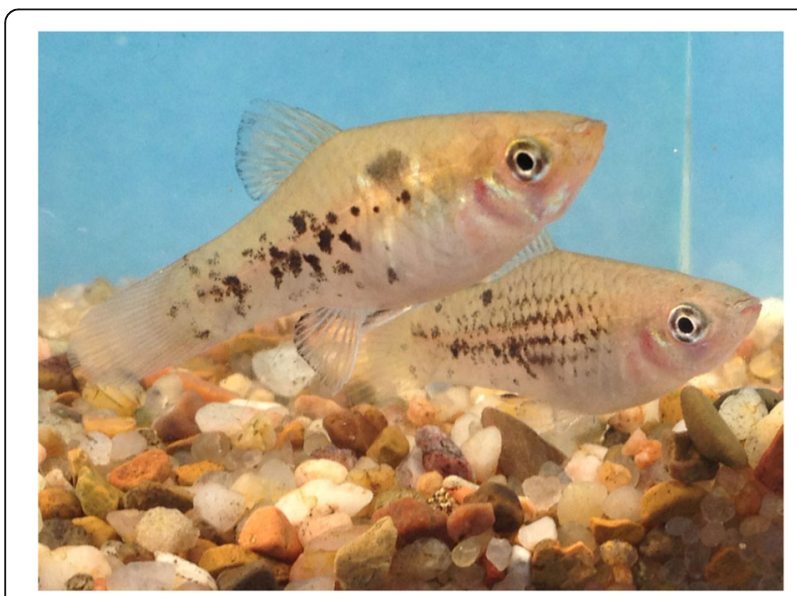

Fig. 2 Example of Xiphophorus maculatus Jp 163 B male (bottom) and female (top). Male siblings in their 105th generation of brothersister line breeding were utilized for the experiment detailed herein types of common fluorescent light sources $(311 \mathrm{~nm}$ UVB, $4100 \mathrm{~K}$ or "cool white" FL, and 10,000 K or "sunlight" FL) [15-19], and to specific light wavebands between 300 and $600 \mathrm{~nm}[20]$.

Our recent studies establish exposure of Xiphophorus to commonly used FL leads to light source specific genetic signatures in the skin, and suggest each different light source may be expected to induce a different "homeogenetic" state in skin. Additionally, previous results of $50 \mathrm{~nm}$ waveband exposures, between 300 and $600 \mathrm{~nm}$, have shown that each $50 \mathrm{~nm}$ waveband incites both unique, and a collective common set of shared, genetic responses. However, interestingly, two select $50 \mathrm{~nm}$ wavebands (350-400 nm, and 500-550 nm) exhibited more robust transcriptional effects than other wavebands tested in the $300-600 \mathrm{~nm}$ region [19].

Herein we present genetic responses of $X$. maculatus skin to FL exposure compared to exposure to 50 and $10 \mathrm{~nm}$ wavebands of light. We show that exposure of the intact animal to select $50 \mathrm{~nm}$ or $10 \mathrm{~nm}$ wavebands of light serves to induce waveband specific effects on the transcription of gene sets representing common genetic pathways. These novel results establish waveband specific transcriptional regulation of genetic pathways, and suggest experimental exposure to different light wavebands may be utilized to specifically up- or downregulate gene expression within the same pathway. Should these novel waveband specific genetic effects be translatable to other vertebrate or mammalian systems, these results suggest select light waveband exposures may be employed as a facile regulator of genetic homeostasis to enhance experimental or therapeutic outcomes. We hypothesize that waveband specific genetic effects are deeply embedded in the vertebrate genetic repertoire and that once understood they may become useful tools for genetic engineering and gene therapy.

\section{Results \\ Differential genetics of exposure to $4100 \mathrm{~K}$ ("cool white") \\ FL light}

Robust changes in the transcriptional state of Xiphophorus skin after exposure to various light sources have been reported [15-20]. For example, $X$. maculatus exposed to $35 \mathrm{~kJ} / \mathrm{m}^{2} \mathrm{FL}$ differentially modulates 413 genes that were analyzed using the Ingenuity Pathway Analysis (IPA; Qiagen, Redwood City, CA.) software suite. Of these 413 genes, 391 genes (95\% of the overall response) were able to be categorized into 74 statistically significant functional classes (z-score $\geq|2| ; 5$ gene minimum; Fig. 3); the remaining $5 \%$ of the dataset either failed to fall into a statistically significant functional class or could not be properly annotated and mapped by IPA. The 74 functional classes represent 10 primary categories; cell cycle; cellular assembly and organization; cellular movement; cellular 


\begin{tabular}{|c|c|c|c|c|c|c|c|c|c|c|c|}
\hline Category & $\begin{array}{c}\text { Cell } \\
\text { Function }\end{array}$ & Functional Class & $p$-value & z-score & Gene \# & Category & $\begin{array}{c}\text { Cell } \\
\text { Function }\end{array}$ & Functional Class & $p$-value & z-score & Gene \# \\
\hline \multirow{14}{*}{ Cell Cycle } & \multirow{5}{*}{$\begin{array}{l}\text { cell cycle } \\
\text { progression }\end{array}$} & $\begin{array}{l}\text { M phase of tumor cell } \\
\text { lines }\end{array}$ & $8.47 \mathrm{E}-22$ & -2.63 & 26 & \multirow{23}{*}{$\begin{array}{l}\text { Organismal Injury } \\
\text { and Abnormalities }\end{array}$} & \multirow{18}{*}{ cancer } & $\begin{array}{l}\text { digestive organ } \\
\text { tumor }\end{array}$ & $5.1 \mathrm{E}-19$ & -2.43 & 354 \\
\hline & & $\begin{array}{l}\text { M phase } \\
\text { phtrats }\end{array}$ & $\frac{1.22 E-29}{1.37-16}$ & $\begin{array}{l}-2.52 \\
-2.29\end{array}$ & $\frac{47}{22}$ & & & digestive system & 3.27E-19 & -2.41 & 353 \\
\hline & & S phase & $1.44 E-08$ & -2.06 & 16 & & & colorectal neoplasia & $1.27 \mathrm{E}-13$ & -2.17 & 233 \\
\hline & & $\begin{array}{l}\text { entry into interphase } \\
\text { of oocytes }\end{array}$ & $1.36 \mathrm{E}-07$ & -2.00 & 4 & & & $\begin{array}{l}\text { liver tumor } \\
\text { lalign }\end{array}$ & $9.09 \mathrm{E}-07$ & -2.09 & 170 \\
\hline & & G2/M phase & $3.32 \mathrm{E}-10$ & -2.00 & 26 & & & $\begin{array}{l}\text { malingant neoplasm } \\
\text { of large intestine }\end{array}$ & $2.77 E-16$ & -2.00 & 306 \\
\hline & \multirow{9}{*}{ mitosis } & $\begin{array}{l}\text { cellular } \\
\text { recombination }\end{array}$ & $2.35 \mathrm{E}-10$ & -3.06 & 16 & & & $\begin{array}{l}\text { colorectal cancer } \\
\text { abdominal carcinoma }\end{array}$ & $\begin{array}{l}6.95 \mathrm{E}-13 \\
8.14 \mathrm{E}-10\end{array}$ & $\begin{array}{l}-2.00 \\
2.00\end{array}$ & $\begin{array}{l}229 \\
265\end{array}$ \\
\hline & & homologous & $1.58 \mathrm{E}-10$ & -2.97 & 18 & & & hematologic cancer & $1.34 \mathrm{E}-08$ & & \\
\hline & & $\begin{array}{l}\text { recombination } \\
\text { homologous }\end{array}$ & & & & & & $\begin{array}{c}\text { hematological } \\
\text { neoplasia }\end{array}$ & $3.13 \mathrm{E}-08$ & 2.06 & 130 \\
\hline & & $\begin{array}{l}\text { recombination of } \\
\text { cells }\end{array}$ & $3.94 \mathrm{E}-08$ & -2.90 & 13 & & & $\begin{array}{l}\text { lymphoproliferative } \\
\text { malignancy }\end{array}$ & $5.37 \mathrm{E}-07$ & 2.06 & 118 \\
\hline & & cytokinesis & $4.7 \mathrm{E}-16$ & -2.69 & 29 & & & mammary tumor & $\begin{array}{l}9.55 \mathrm{E}-14 \\
113 \mathrm{E}-10\end{array}$ & 2.13 & 114 \\
\hline & & $\begin{array}{l}\text { homoloogous } \\
\text { recombination of }\end{array}$ & $1.44 \mathrm{E}-08$ & -2.40 & 8 & & & $\begin{array}{l}\text { carcinoma in lung } \\
\text { Iymphoid cancer }\end{array}$ & $\begin{array}{l}1.133-10 \\
1.89 \mathrm{E}-07\end{array}$ & $\begin{array}{l}2.14 \\
2.15\end{array}$ & $\begin{array}{l}86 \\
120\end{array}$ \\
\hline & & $\begin{array}{l}\text { DNA } \\
\text { Dytangsiof fum }\end{array}$ & & & & & & $\begin{array}{l}\text { tumorigenesis of } \\
\text { reproductive tract }\end{array}$ & $2.86 \mathrm{E}-13$ & 2.18 & 182 \\
\hline & & $\begin{array}{l}\text { cell lines } \\
\text { formation of mitotic }\end{array}$ & $1.58 \mathrm{E}-12$ & -2.07 & 15 & & & $\begin{array}{l}\text { non-small cell lung } \\
\text { cancer }\end{array}$ & 3.43E-10 & 2.19 & 83 \\
\hline & & $\begin{array}{c}\text { formation of mitotic } \\
\text { spindle }\end{array}$ & $1.37 \mathrm{E}-16$ & 2.04 & 19 & & & non small cell lung & 7.6E-09 & 2.20 & 67 \\
\hline \multirow{8}{*}{$\begin{array}{l}\text { Cellular } \\
\text { Assembly and } \\
\text { Organization }\end{array}$} & \multirow{5}{*}{ chromosome } & $\begin{array}{l}\text { aneuploidy } \\
\text { association of } \\
\text { chromatin }\end{array}$ & $\begin{array}{l}2.78 \mathrm{E}-06 \\
1.39 \mathrm{E}-11\end{array}$ & $\frac{2.52}{-2.78}$ & $\frac{10}{9}$ & & & $\begin{array}{l}\text { neoplasia of } \\
\text { leukocytes }\end{array}$ & $1.2 \mathrm{E}-05$ & 2.36 & 23 \\
\hline & & $\begin{array}{c}\text { chromosomal } \\
\text { chnoression of }\end{array}$ & $14 \mathrm{E}-18$ & -254 & 11 & & & $\begin{array}{l}\text { T-cell non-Hodgkin's } \\
\text { disease }\end{array}$ & $1.52 \mathrm{E}-06$ & 2.36 & 20 \\
\hline & & chromosomes & $1.4 E-10$ & -2.04 & $\pi$ & & & hematologic cancer & $1.76 \mathrm{E}-05$ & 2.38 & 22 \\
\hline & & $\begin{array}{l}\text { chromosomal } \\
\text { alignment } \\
\text { association of }\end{array}$ & $8.77 E-23$ & -2.49 & 17 & & & $\begin{array}{l}\text { lymphocytis cancer } \\
\text { adenocarcinomat }\end{array}$ & $\begin{array}{l}9.57 \mathrm{E}-09 \\
7.1 \mathrm{E}-17\end{array}$ & $\begin{array}{l}2.60 \\
2.94\end{array}$ & $\begin{array}{r}50 \\
342\end{array}$ \\
\hline & & $\begin{array}{l}\text { association of } \\
\text { chromosome } \\
\text { components }\end{array}$ & $6.07 E-11$ & -2.16 & 10 & & \multirow{3}{*}{ incidence } & $\begin{array}{l}\text { incidence of } \\
\text { lymphoma }\end{array}$ & $\begin{array}{l}1.1 \mathrm{E}-\mathrm{E}-08 \\
6.56 \mathrm{E}-08\end{array}$ & 2.21 & 14 \\
\hline & \multirow{3}{*}{ organization } & $\begin{array}{c}\text { cytoplasm } \\
\text { organization }\end{array}$ & $3.29 \mathrm{E}-09$ & -3.25 & 82 & & & $\begin{array}{l}\text { incidence of } \\
\text { malignant tumor }\end{array}$ & $1.48 \mathrm{E}-08$ & 2.89 & 20 \\
\hline & & $\begin{array}{l}\text { Cytoskeleteon } \\
\text { organization }\end{array}$ & $6.6 \mathrm{E}-08$ & -3.25 & 73 & & & $\begin{array}{l}\text { incidence of tumor } \\
\text { lipid oxidation }\end{array}$ & $\begin{array}{l}4.67 \mathrm{E}-11 \\
5.15 \mathrm{E}-05\end{array}$ & $\frac{2.96}{2.11}$ & $\frac{31}{26}$ \\
\hline & & $\begin{array}{l}\text { microtubule } \\
\text { arrangement }\end{array}$ & $6.31 \mathrm{E}-06$ & -2.83 & 59 & & \multirow[t]{2}{*}{ disease } & $\begin{array}{l}\text { non-Hodgkin's } \\
\text { disease }\end{array}$ & $3.41 \mathrm{E}-07$ & 2.37 & 37 \\
\hline \multirow{2}{*}{$\begin{array}{l}\text { Cellular } \\
\text { Movement }\end{array}$} & \multirow[b]{2}{*}{ division } & cytokinesis & $4.7 \mathrm{E}-16$ & -2.69 & 29 & & & death of embryo & $1.72 E-12$ & 3.43 & 22 \\
\hline & & $\begin{array}{l}\text { cytokinesis of tumor } \\
\text { cell lines }\end{array}$ & $1.58 \mathrm{E}-12$ & -2.07 & 15 & \multirow{9}{*}{$\begin{array}{l}\text { Immunological } \\
\text { Disease }\end{array}$} & \multirow{3}{*}{ disease } & $\begin{array}{l}\text { lipid oxidation } \\
\text { T-cell non-Hodgkin's }\end{array}$ & 5.15E-05 & 2.11 & 26 \\
\hline \multirow{6}{*}{$\begin{array}{l}\text { Cellular Growth } \\
\text { and Proliferation }\end{array}$} & \multirow{6}{*}{ proliferation } & $\begin{array}{l}\text { Cell proliferation } \\
\text { cell proliferation of }\end{array}$ & $2.29 E-15$ & -5.98 & 176 & & & $\begin{array}{l}\text { disease } \\
\text { non-Hodgkin's }\end{array}$ & $1.52 E=-06$ & 2.36 & 20 \\
\hline & & tumor cell lines & $1.55 \mathrm{E}-07$ & -4.39 & 79 & & & $\begin{array}{l}\text { disease } \\
\text { disis }\end{array}$ & $3.41 \mathrm{E}-07$ & 2.37 & 37 \\
\hline & & $\begin{array}{l}\text { polineration of } \\
\text { connective tissue }\end{array}$ & $2.15 \mathrm{E}-06$ & -3.57 & 36 & & & $\begin{array}{l}\text { lymphoproliferative } \\
\text { malignancy }\end{array}$ & $5.37 \mathrm{E}-07$ & 2.06 & 118 \\
\hline & & $\begin{array}{l}\text { cells } \\
\text { cell proliferation of }\end{array}$ & 0350 & 297 & 28 & & & Iymphoma & $6.56 \mathrm{E}-08$ & $\begin{array}{l}2.21 \\
2.29\end{array}$ & 14 \\
\hline & & $\begin{array}{l}\text { breast cancer cell } \\
\text { lines }\end{array}$ & $9.3 E-06$ & -2.97 & 28 & & cancer & $\begin{array}{l}\text { DNA damage } \\
\text { neoplasia of }\end{array}$ & $5.05 E-12$ & 2.23 & 23 \\
\hline & & $\begin{array}{l}\text { cell prolifieration of } \\
\text { fibroblasts }\end{array}$ & $4.99 \mathrm{E}-08$ & -2.56 & 28 & & & $\begin{array}{l}\text { leukocyytes } \\
\text { T-cell }\end{array}$ & $1.25-00$ & 2.00 & 20 \\
\hline \multirow{15}{*}{$\begin{array}{l}\text { DNA Replication, } \\
\text { Recombination, } \\
\text { and Repair }\end{array}$} & \multirow[b]{2}{*}{ repair } & $\begin{array}{l}\text { DNA repair } \\
\text { matsm of }\end{array}$ & $\begin{array}{l}3.6 E-23 \\
485-17\end{array}$ & $\begin{array}{l}-3.34 \\
-323 \\
\end{array}$ & $\frac{45}{44}$ & & & $\begin{array}{l}\text { lymphoproliferative } \\
\text { dissorder }\end{array}$ & $1.83 \mathrm{E}-05$ & 2.36 & 22 \\
\hline & & checkpoint control & 1.37 E-16 & $-\frac{-2.29}{2.9}$ & $\frac{22}{25}$ & & & lymphocytic cancer & $9.57 \mathrm{E}-09$ & 2.60 & 50 \\
\hline & replication & $\begin{array}{l}\text { DNA damage } \\
\text { DNA replication }\end{array}$ & $\begin{array}{l}5.05 \mathrm{E}-12 \\
2.76 \mathrm{E}-20\end{array}$ & $\begin{array}{l}2.29 \\
-2.66\end{array}$ & $\frac{25}{38}$ & & & $\begin{array}{l}\text { cell death of cervical } \\
\text { cancer cell lines }\end{array}$ & $1.19 \mathrm{E}-12$ & 2.32 & 36 \\
\hline & & 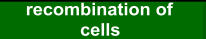 & $2.35 \mathrm{E}-10$ & -3.06 & 16 & & & $\begin{array}{l}\text { apoptosis of germ } \\
\text { cells }\end{array}$ & $1.32 \mathrm{E}-05$ & 2.62 & 13 \\
\hline & & $\begin{array}{l}\text { homologous } \\
\text { recombination }\end{array}$ & $1.58 \mathrm{E}-10$ & -2.97 & 18 & & & $\begin{array}{l}\text { apoptosis of cervical } \\
\text { cancer cell lines }\end{array}$ & $5.5 \mathrm{E}-10$ & 2.79 & 28 \\
\hline & & $\begin{array}{l}\text { homologous } \\
\text { recombination of }\end{array}$ & 3.94E-08 & -2.90 & 13 & & cell death & $\begin{array}{l}\text { apoptosis of tumor } \\
\text { cell lines }\end{array}$ & $6.89 \mathrm{E}-15$ & 3.46 & 83 \\
\hline & & $\begin{array}{l}\text { cells } \\
\text { ang }\end{array}$ & & & & & & cell death of tumor & $1.83 \mathrm{E}-20$ & 3.68 & 108 \\
\hline & & $\begin{array}{l}\text { chromosomomal } \\
\text { congression of } \\
\text { chromosomes }\end{array}$ & $1.4 \mathrm{E}-18$ & -2.54 & 11 & $\begin{array}{l}\text { Cell Death and } \\
\text { Survival }\end{array}$ & & $\begin{array}{l}\text { necrosis } \\
\text { apoptosis }\end{array}$ & $\begin{array}{l}8.59 E-14 \\
7.28=-14\end{array}$ & $\begin{array}{l}4.06 \\
4.15\end{array}$ & $\frac{108}{135}$ \\
\hline & recombination & $\begin{array}{l}\text { chromosomies } \\
\text { chromosomal }\end{array}$ & $8.77 E-23$ & -2.49 & 17 & & & cell death & $\frac{6.6 \mathrm{E}-18}{6.18}$ & 5.03 & 172 \\
\hline & & $\begin{array}{l}\text { alignment } \\
\text { homologous }\end{array}$ & & & & & & $\begin{array}{l}\text { cell survival } \\
\text { cell viability }\end{array}$ & $\begin{array}{l}1.29 \mathrm{E}-11 \\
1.99-11\end{array}$ & $\begin{array}{l}-5.24 \\
-5.08\end{array}$ & $\frac{82}{78}$ \\
\hline & & $\begin{array}{l}\text { recombination of } \\
\text { DNA }\end{array}$ & $1.44 \mathrm{E}-08$ & -2.40 & 8 & & & $\begin{array}{l}\text { cell viablity of tumor } \\
\text { cell lines }\end{array}$ & $2.16 \mathrm{E}-12$ & -4.69 & 58 \\
\hline & & $\begin{array}{l}\text { chromosomal } \\
\text { aberration }\end{array}$ & $1.22 \mathrm{E}-05$ & 2.78 & 12 & & cell survival & $\begin{array}{l}\text { cell viability of } \\
\text { cervical cancer cell }\end{array}$ & $5.07 \mathrm{E}-05$ & -3.39 & 16 \\
\hline & & $\begin{array}{l}\text { chromosomal } \\
\text { instability }\end{array}$ & $9.69 \mathrm{E}-07$ & 2.79 & 8 & & & $\begin{array}{l}\text { lines } \\
\text { repair of cells }\end{array}$ & & & \\
\hline & & breakage of & $2.9 \mathrm{E}-10$ & 3.12 & 12 & & & fatty acid oxidation & $\begin{array}{l}2.0 E-08 \\
2.72-08\end{array}$ & 2.32 & $\frac{14}{12}$ \\
\hline & & $\begin{array}{l}\text { chromosomes } \\
\text { fatty acid oxidation }\end{array}$ & $2.0 E-08$ & 2.32 & 14 & Organismal & organismal & $\begin{array}{l}\text { death of embryo } \\
\text { growth failure }\end{array}$ & $\begin{array}{l}1.72 \mathrm{E}-12 \\
9.66 \mathrm{E}-07\end{array}$ & $\begin{array}{l}3.43 \\
3.61\end{array}$ & $\frac{22}{37}$ \\
\hline & & $\begin{array}{l}\text { proliferation of } \\
\text { connective tissue }\end{array}$ & $2.15 \mathrm{E}-06$ & -3.57 & 36 & Survival & death & $\begin{array}{l}\text { organismal death } \\
\text { Inflammation }\end{array}$ & $\begin{array}{l}2.28 \mathrm{E}-14 \\
7.23 \mathrm{E}-08\end{array}$ & $\begin{array}{l}\frac{7.87}{2.02} \\
\end{array}$ & $\frac{128}{8}$ \\
\hline $\begin{array}{c}\text { Tissue } \\
\text { Development }\end{array}$ & growth & $\begin{array}{l}\text { cells } \\
\text { growth of connective }\end{array}$ & $253 \mathrm{E}-06$ & -338 & & & & & & & \\
\hline Development & & tissue & $2.53 E-06$ & -3.38 & 38 & & & & & & \\
\hline & & fibroblasts & $4.99 \mathrm{E}-08$ & -2.56 & 28 & & & & & & \\
\hline $\begin{array}{l}\text { Fig. } 3 \text { X. macu } \\
\text { overall respons } \\
\text { of the genes } n \\
\text { The } 74 \text { functic } \\
\text { proliferation; }[ \\
\text { disease; and c } \\
\text { highlighting th } \\
\text { remaining } 55 \mathrm{fu}\end{array}$ & $\begin{array}{l}\text { hodulated ei } \\
\text { nal classes } \\
\text { NA replicat } \\
\text { ell death an } \\
\text { gene numb } \\
\text { nctional clas }\end{array}$ & $\begin{array}{l}\text { her failed to fall in } \\
\text { represent } 10 \text { prim } \\
\text { d survival. The } 19 \\
\text { er. Compensatory } \\
\text { ses observed follow }\end{array}$ & $\begin{array}{l}\text { to a statis } \\
\text { ary categ } \\
\text { //repair; } \\
\text { function } \\
\text { effects du } \\
\text { ing FL ex }\end{array}$ & $\begin{array}{l}\text { statistical } \\
\text { stically si } \\
\text { gories; ce } \\
\text { organism } \\
\text { nal classe } \\
\text { de to the } \\
\text { xposure. F }\end{array}$ & $\begin{array}{l}\text { gll cycl } \\
\text { nal sur } \\
\text { es shar } \\
\text { combir } \\
\text { Eor con }\end{array}$ & $\begin{array}{l}\text { nctional class } \\
\text { Ilular assemb } \\
\text { tissue devel } \\
\text { etween FL ar } \\
\text { xposure by m } \\
\text { e gene lists of }\end{array}$ & $\begin{array}{l}\text { could not } \\
\text { couscore } \\
\text { organizati } \\
\text { ment; org } \\
\text { the } 50 \text { or } \\
\text { iple waveb } \\
\text { ch functior }\end{array}$ & $\begin{array}{l}\text { using IPA (Qiagen) } \\
\pm 2 ; 5 \text { gene minim } \\
\text { oe properly annot } \\
\text { n; cellular moven } \\
\text { nismal injury/abn } \\
10 \mathrm{~nm} \text { waveband } \\
\text { ands is assumed to } \\
\text { al class see Additio }\end{array}$ & $\begin{array}{l}391 \text { ger } \\
\text { hum); the } \\
\text { ated and } \\
\text { nent; cel } \\
\text { ormality; } \\
\text { ds are sh } \\
\text { be respo } \\
\text { nal file 2: }\end{array}$ & $\begin{array}{l}\text { es }(95 \% \\
\text { remaini } \\
\text { mapped } \\
\text { ular gro } \\
\text { immunc } \\
\text { own by } \\
\text { nsible fo } \\
\text { Table S2 }\end{array}$ & $\begin{array}{l}\text { of the } \\
\text { ng } 5 \% \\
\text { by IPA. } \\
\text { wth/ } \\
\text { ological } \\
\text { color } \\
\text { r the } \\
\text { a }\end{array}$ \\
\hline
\end{tabular}


growth and proliferation; DNA replication, recombination and repair; organismal survival; tissue development; organismal injury and abnormality; immunological disease; and cell death and survival. The largest predicted functional effects, based on modulated transcriptional profiles following FL exposure, in male $X$. maculatus skin are suppression of cell growth/cell proliferation and an increase in organismal injury and abnormalities (Fig. 3). Due to the large effect FL exposure has on DNA replication, recombination and repair, coupled with cell cycle progression and cellular growth, it was not unexpected to see functional classes related to the onset of cancer where FL modulated genes are involved in several overlapping pathways, all related to cell proliferation. Suppression of cellular growth and proliferation has previously been suggested [19], and the results reported here represent 176 unique genes or approximately $43 \%$ of the total differentially modulated genes in the FL dataset. Supporting the suppression of cell growth and proliferation is the suppression of cell cycle progression (64 unique genes, 15\% of the total dataset). While this encompasses the largest predicted response to $\mathrm{FL}$, the overall transcriptional response to $\mathrm{FL}$ exposure is very complex and made up of multiple components that we suspected may directly reflect the spectral peaks emitted by FL. Surprisingly, although the spectral distribution is outside of the UVB and UVA range, genes associated with cell death are significantly represented (172 genes, $\mathrm{z}$-score 5.03, $p$-value 6.4E-18) and indicate a potential suppression of cell viability and an increase in cell death through apoptosis and necrosis.

\section{Exposure to varied $50 \mathrm{~nm}$ wavebands leads to unique genetic responses}

To attempt to assign wavelengths, and possibly FL spectral peaks represented in discrete wavebands, to the observed transcriptional effects predicting altered cellular functional pathways, we exposed male $X$. maculatus fish to $50 \mathrm{~nm}$ wavebands spanning the FL spectrum $(350-600 \mathrm{~nm})$. Gene sets involved with 19 of the functional classes transcriptionally modulated by FL were also found modulated after exposure of the animals to select $50 \mathrm{~nm}$ wavebands (Figs. 3 and 4). The 19 functional classes are shared in $\mathrm{FL}$, and at least one $50 \mathrm{~nm}$ waveband, are highlighted in Fig. 3 (colored columns at right) and shown at the far left of Fig. 4. In both Figs. 3 and 4 the numbers of genes assigned to each functional class, ranging from 8 to 176, are shown in the appropriate colored box, where the color represents the direction (i.e., red, up-regulated and green, downregulated) and magnitude (i.e., fold change or z-score color bars) of the response. Based on these results, compensatory effects due to the combined exposure inherent to the complex $4100 \mathrm{~K}$ FL emission spectrum are

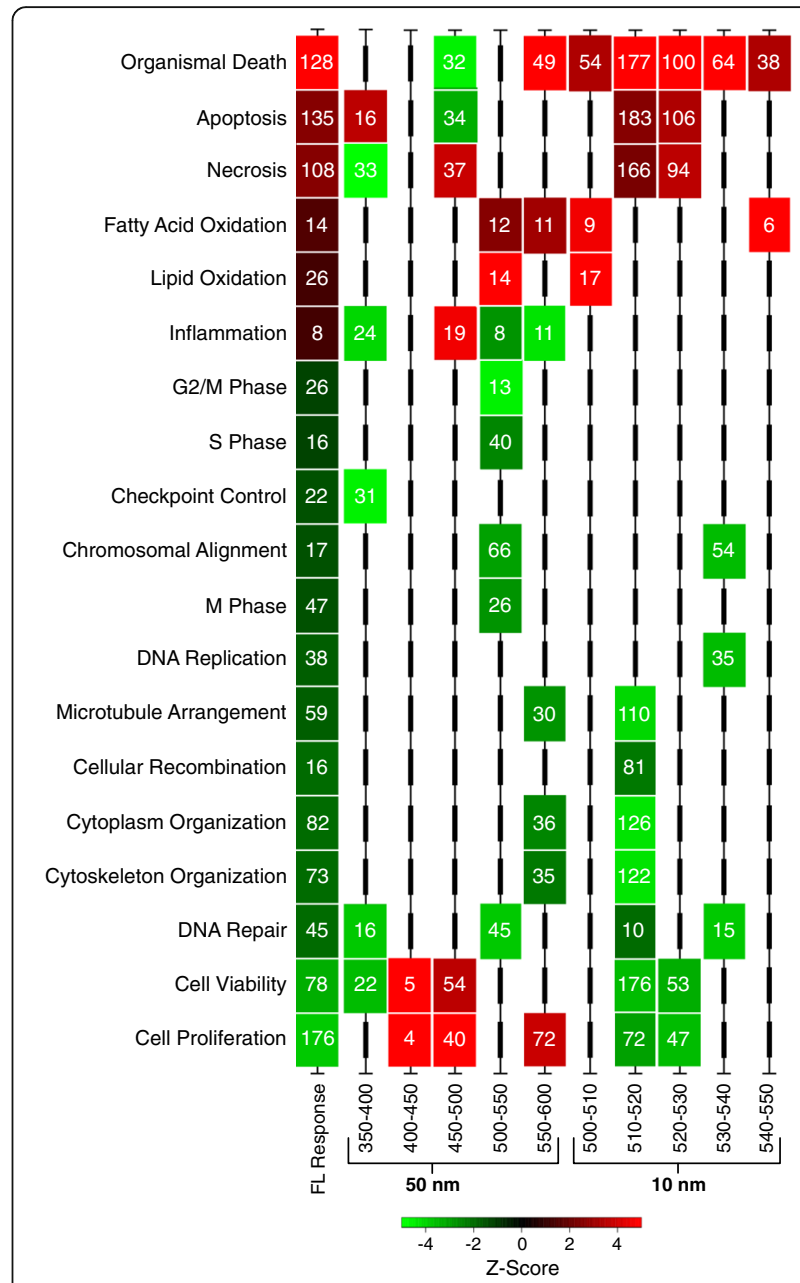

Fig. 4 Functional classes ( $z$-score $\geq|2|$ ) were compared through the wavebands using Qiagen's IPA software and plotted if they were shared with FL in any waveband from 350 to $600 \mathrm{~nm}$. Heat map color represents IPA classified z-score (red is up and green is down) and the number inside each box represents the number of genes contributing to the functional effect. For complete gene lists of each functional class see Additional file 4: Table S4a-k

assumed to be responsible for modulation of the remaining 55 specific functional classes observed following FL exposure, but not incited by $50 \mathrm{~nm}$ waveband exposures.

We have previously reported transcriptional effects of $50 \mathrm{~nm}$ waveband exposure in male Xiphophorus skin unexpectedly showed two wavebands $(350-400 \mathrm{~nm}$ and $\left.500-550 \mathrm{~nm} ; \log _{2} \mathrm{FC}, \mathrm{fdr} \leq 0.05\right)$ that were able to incite significantly higher differential gene expression compared to any of the other $50 \mathrm{~nm}$ wavebands between 300 and $600 \mathrm{~nm}$ [20]. In these studies, we showed that exposure to either $350-400$ or $500-550 \mathrm{~nm}$ wavebands led to modulation of circadian gene activity and altered the activity of TP53 gene targets, but via very different regulatory mechanisms; ATM at 350-400 and ATR at 
500-550 nm [20]. Additionally, exposure to only the $500-550 \mathrm{~nm}$ waveband induced genes associated with cellular stress as a major response, while this gene set was not present in the genes showing differential transcription after exposure to the 350-400 nm waveband.

Further analysis of the $50 \mathrm{~nm}$ waveband exposure results led to identification of transcriptional responses that show opposite directional modulation of genes associated with major cellular pathways, such as necrosis and apoptosis. For example, X. maculatus skin exposed to $350-400 \mathrm{~nm}$ light (Fig. 4 and Additional file 1: Table S1) exhibit down modulation of transcription in 33 genes that collectively would be expected to produce a decrease in necrosis; however, exposure of the same fish $(>100$ generations inbred) to the same dose of $\mathrm{FL}$, or the 450-500 nm waveband, leads to substantial upregulation of $108(\mathrm{FL})$ or $37(450-500 \mathrm{~nm})$ genes, involved with necrosis, and predicted to produce an overall increase in necrosis. Similarly, 450-500 nm exposure transcriptionally down-modulates 34 genes that predict an overall decrease in apoptosis (Fig. 4), but exposure to $\mathrm{FL}$, or the $350-400 \mathrm{~nm}$ waveband, leads to increased transcription of apoptosis associated genes (Fig. 4; 135 for FL and 16 up-modulated for 350$400 \mathrm{~nm}$, respectively). This opposite effect on transcription of necrosis and apoptosis associated genes after exposure to FL, or select $50 \mathrm{~nm}$ wavebands of light, may not occur in exactly the same gene targets (Additional file 1: Table S1), but does involve genes associated with necrosis and apoptosis function based on their similarity with human genes (e.g., assigned HUGO id's) and functional clustering by IPA software. In any case, the results shown in Fig. 4 serve as examples of waveband selective transcriptional modulation among multiple specific gene targets within multigenetic functional pathways. Other examples of waveband selective transcriptional modulation within functional pathways, and/or oppositely modulated transcriptional effects among the $50 \mathrm{~nm}$ exposures are presented in Additional file 1: Table S1, both for FL and each $50 \mathrm{~nm}$ waveband.

\section{Select waveband exposures show increased specificity of gene expression patterns}

To better understand the $50 \mathrm{~nm}$ waveband results regarding differential transcription of select pathways, we also exposed fish to $10 \mathrm{~nm}$ wavebands in the most gene responsive $50 \mathrm{~nm}$ waveband (i.e., $500-550 \mathrm{~nm}$ ) [20]. Table 1 shows transcriptionally modulated gene numbers for $4100 \mathrm{~K} \mathrm{FL}$, the $50 \mathrm{~nm}$ wavebands between 300 and $600 \mathrm{~nm}$, and for $10 \mathrm{~nm}$ wavebands within the $500-550 \mathrm{~nm}$ region. Interestingly, the overall numbers of genes modulated for each exposure is not matched to waveband width or spectral complexity, but each appears
Table 1 Numbers of genes transcriptionally up-modulated, down-modulated and total after exposure to FL or each of the various wavebands

\begin{tabular}{llll}
\hline Exposure & Up & Down & Total \\
\hline $4100 \mathrm{~K} \mathrm{FL}$ & 52 & 361 & 413 \\
$350-400 \mathrm{~nm}$ & 59 & 58 & 117 \\
$550-550 \mathrm{~nm}$ & 177 & 168 & 345 \\
$500-510 \mathrm{~nm}$ & 82 & 141 & 223 \\
$510-520 \mathrm{~nm}$ & 233 & 530 & 763 \\
$520-530 \mathrm{~nm}$ & 169 & 241 & 410 \\
$530-540 \mathrm{~nm}$ & 90 & 189 & 279 \\
$540-550 \mathrm{~nm}$ & 45 & 116 & 161 \\
\hline
\end{tabular}

to have unique properties unto itself. For example, the $10 \mathrm{~nm}$ waveband between 510 and 520 shows more genes transcriptionally modulated (763) than any other exposure, even more than exposure to the comparatively complex $4100 \mathrm{~K}$ FL spectra (413). In contrast, the 540$550 \mathrm{~nm}$ waveband shows very few transcriptionally modulated genes (162 genes), compared to the other $10 \mathrm{~nm}$ waveband exposures.

In Fig. 4, the 19 functional pathways exhibiting the largest degree of transcriptional modulation after exposure to $4100 \mathrm{~K} \mathrm{FL}$, that are shared in at least one differentially regulated functional gene class after the $50 \mathrm{~nm}$ or $10 \mathrm{~nm}$ waveband exposures, is presented. The functional class box color in Fig. 4 represents the degree of up- (red) or down-regulation (green) based on the zscore (inset color bar). These functional classes of light waveband responsive genes represent the most affected pathways for $4100 \mathrm{~K} \mathrm{FL}, 50$, and $10 \mathrm{~nm}$ exposures, as determined by the numbers of genes modulated. For each functional class of genes represented, the numbers of differential transcriptionally modulated genes are shown inside functional class boxes. The FL dose was $35 \mathrm{~kJ} / \mathrm{m}^{2}$, while does of all waveband exposures were $\approx 18 \mathrm{~kJ} / \mathrm{m}^{2}$. As shown, some of the gene sets exhibiting predicted transcriptional effects in a functional class that are incited by FL exposure are observed to segregate into specific $50 \mathrm{~nm}$ exposures. For example, the 500 $550 \mathrm{~nm}$ waveband incited the most robust transcriptional response, modulating 8 of the 19 functional classes initially observed in the $4100 \mathrm{~K} \mathrm{FL}$ exposure and representing $224(65 \%)$ of the total 345 genes modulated among the 19 classes. Transcriptional modulation of these eight classes of genes after 500-550 nm exposure largely mirrored the direction (i.e. up- or down-modulation) and gene numbers modulated after $4100 \mathrm{~K}$ FL exposure, with a few exceptions (e.g., Chromosomal alignment/Movement, $\mathrm{S}$ phase showing higher numbers of genes effected, while $M$ and $G 2 / M$ phases showed lower numbers of effected genes). This suggests the large-scale suppression 
of cell cycle associated genes previously reported for FL exposure [19] is principally due to the $500-550 \mathrm{~nm}$ waveband, a minor component of the $4100 \mathrm{~K}$ FL spectrum (Fig. 1).

Aside from the 500-550 $\mathrm{nm}$ waveband, the other $50 \mathrm{~nm}$ waveband exposures each exhibited only a few shared functional class transcriptional effects observed for FL exposure (e.g., 400-450-2, 450-500 - 4, and both $350-400$ and $550-600 \mathrm{~nm}$ shared modulation in 5 of the 19 functional classes). Thus, many of the $4100 \mathrm{~K} \mathrm{FL}$ functional class responses were segregated into separate $50 \mathrm{~nm}$ wavebands. However, in many cases the waveband specific transcriptional effects were opposite in direction, when compared to the corresponding effected group of genes after FL exposure. For example, the 450$500 \mathrm{~nm}$ waveband exhibited exclusive increased transcription of genes associated with inflammation (19 genes), cell viability (54 genes) and cell proliferation (40 genes). Concurrently, the 450-500 nm waveband exposed skin exhibited decreased transcription in genes associated with organismal death (32 genes), and apoptosis (34 genes), but interestingly, up-regulated genes associated with necrosis. With the exception of necrosis and inflammation, the $450-500 \mathrm{~nm}$ waveband served to transcriptionally up-modulate functional class gene sets in the opposite direction from $4100 \mathrm{~K}$ FL exposure.

There appear many classes of genes among the $50 \mathrm{~nm}$ waveband exposures that exhibit waveband specific transcriptional response, or show, waveband specific and opposite transcriptional response, compared to exposure by the complex FL light source (e.g., note alternating green and red boxes as one moves from left FL to the right within the $50 \mathrm{~nm}$ bands of Fig. 4).

To further investigate waveband specific transcriptional responses, we exposed fish to successive $10 \mathrm{~nm}$ wavebands within the most responsive $50 \mathrm{~nm}$ waveband (i.e., 500-550 nm; Fig. 4, right and Additional file 2: Table S2 g-k). Here we make three summative observations; (1) there are much greater numbers of genes affected in many of the $10 \mathrm{~nm}$ functional classes than in the corresponding $50 \mathrm{~nm}$ or FL functional class. For example, "organismal death" has 22 genes modulated after $4100 \mathrm{~K} \mathrm{FL}$, while the 510-520 nm exposure shows 177 modulated genes in this class. In the "microtubule arrangement" class, $4100 \mathrm{~K}$ FL exposure led to transcriptional modulation of 59 genes, whereas the $510-520 \mathrm{~nm}$ exposure shows 110. (2) There appears a higher degree of functional specificity segregating into specific $10 \mathrm{~nm}$ exposures than observed in the $50 \mathrm{~nm}$ exposures. For example, the 500-510 $\mathrm{nm}$ exposure only up-regulates lipid metabolism functions, $510-520 \mathrm{~nm}$ seems to primarily down-regulate cell division and correspondingly up-regulate organismal death, $520-530 \mathrm{~nm}$ is central to cell death and necrosis pathways, $530-540 \mathrm{~nm}$ primarily affects genes involved in DNA replication, repair and chromosome structure which are likely overlapping functions of the same genes, whereas 540-550 nm exposure is rather innocuous, only up-regulating four genes involved with fatty acid biosynthesis. (3) The greatest effects of FL or 500-550 nm exposures in skin are sequestered into only 3 of the $10 \mathrm{~nm}$ exposures (i.e., $30 \mathrm{~nm}$ between 500 and $530 \mathrm{~nm}$ ). There is a split in functional responses between the $500-510 \mathrm{~nm}$ and 510 $520 \mathrm{~nm}$. Although these exposures are only $10 \mathrm{~nm}$ apart, the transcriptional responses at $500-510 \mathrm{~nm}$ (lipid metabolism) and 510-520 $\mathrm{nm}$ (cell reorganization and cell death) are expected to have very little overlap in function and result in very different effects in the skin.

Waveband dependent differentially regulated transcriptional gene clusters were further analyzed for effects on specific genetic and/or biochemical pathways. For example, Fig. 5 shows the epidermal growth factor $(E G F)$ pathway may be experimentally manipulated by varied waveband exposures. The EGF response shows suppression in $4100 \mathrm{~K} \mathrm{FL}$ exposed skin (green colored gene targets, Fig. 5), then switches to exhibit transcriptional activation after 450-500 nm exposure (red colored gene targets, Fig. 4), then once again exhibits transcriptional suppression upon exposure to 510$520 \mathrm{~nm}$ light. As shown, gene target responses within the EGF pathway transcriptionally suppressed by $4100 \mathrm{~K}$ FL exposure (Fig. 5, top) involve, JAK1, PLCG1, and $P I 3 K$ regulators. However, after organismal exposure to $450-500 \mathrm{~nm}$ light, this same pathway is highly transcriptionally up-regulated (Fig. 5, middle) with SOS, RAS, PI3K regulators all showing enhanced transcription. Exposure to $520-530 \mathrm{~nm}$ waveband light once again exhibits suppression of $E G F$ pathway through reduced transcription of EGFR, PLCG1, SHC, PI3K, PKC, STAT1, STAT3, CK2 and LK1 (Fig. 5, bottom).

The EGF situation shown in Fig. 5, wherein different waveband exposures lead to opposite transcriptional regulation of discrete pathways is not uncommon in $X$. maculatus skin. In Fig. 6, we show 25 functional classes based upon modulated transcription of gene sets that clearly exhibit opposite transcriptional responses between any two of the FL, $50 \mathrm{~nm}$ or $10 \mathrm{~nm}$ waveband exposures (Fig. 6, note color change from red to green in boxes as one moves from left to right). Within the functional classes, that each exhibit waveband specific regulation, are many specific biochemical and/or genetic pathways that may be manipulated by specific waveband exposures of the intact animal. Additional file 1: Table S1 presents all functional classes that are either uniquely regulated with specific waveband exposures, or are oppositely regulated by any two of the $50 \mathrm{~nm}$ or $10 \mathrm{~nm}$ waveband exposures, along with numbers of genes transcriptionally modulated in each class. 


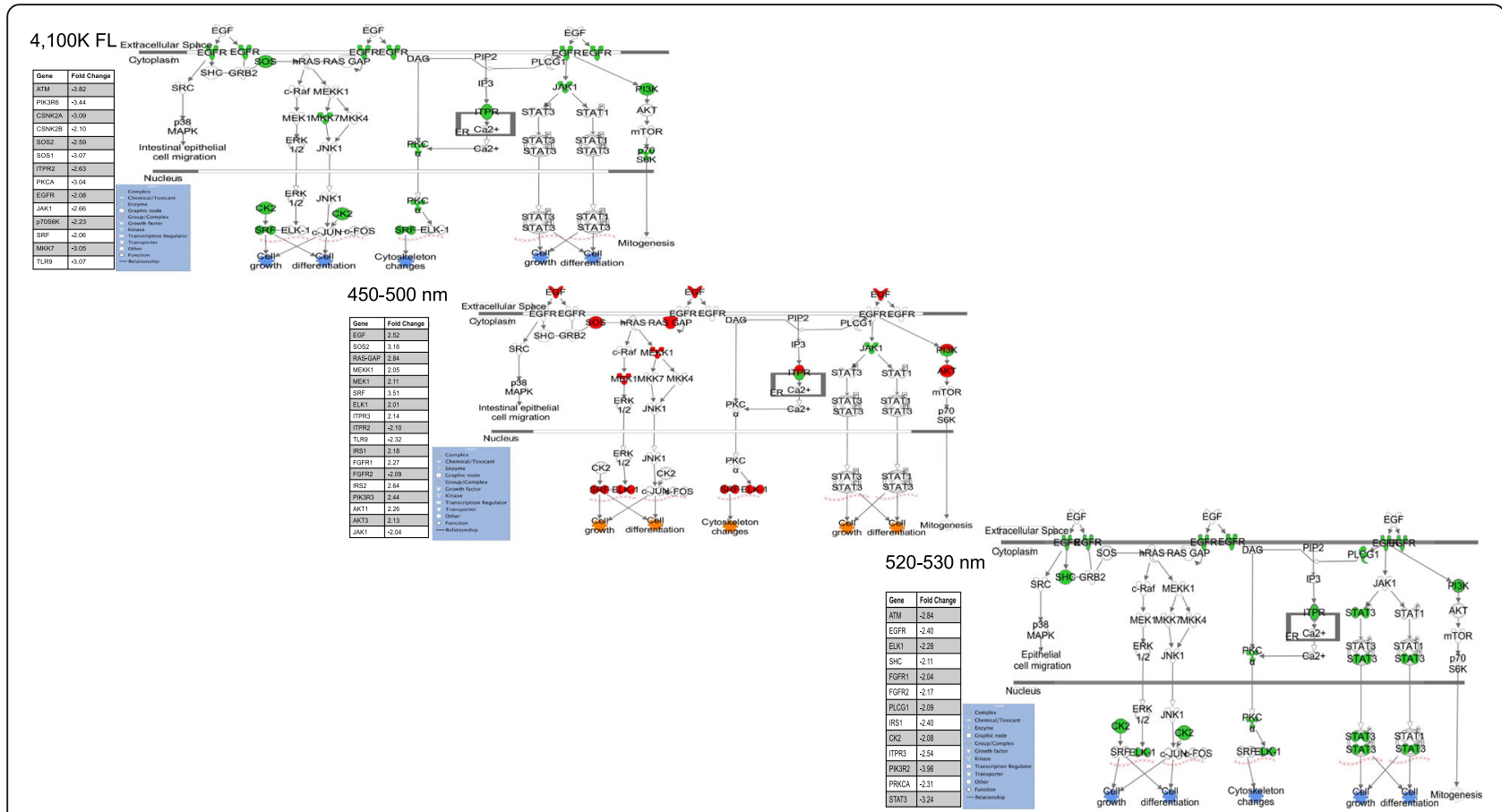

Fig. 5 Waveband specific differential transcriptional regulation of the epidermal growth factor (EGF) pathway. The EGF pathway is suppressed when fish are exposed to $4100 \mathrm{~K} \mathrm{FL}$ or 520-530 nm waveband light (top and bottom). In these two cases, the transmembrane EGF receptor is down-modulated as are many downstream gene targets of the pathway. However, when the fish are exposed to 450-500 nm waveband light (center) EGF transcription is up-modulated. The EGFR is present and predicted to be ligand bound leading to up-regulated transcription of most downstream targets. Each molecule differentially up modulated is represented in red and down represented in green. Downstream effects are predicted to be activated (orange) or suppressed (blue) based on IPA z-score. Complexes consist of multiple genes represented by a single symbol in the figure (4100 K: PI3K-TLR9, PIK3R6, ATM; SOS-SOS1, SOS2; ITPR-ITPR2; CK2-CSNK2A, CSNK2B. $450-500$ nm: SOS-SOS2; ITPR-ITPR2, ITPR3; PI3K-TLR9, IRS1, FGFR1, FGFR2, IRS2, PIK3R3; AKT-AKT1, AKT3. 520-530 nm: ITPR-ITPR3, PI3K-ATM, FGFR1, FGFR2, IRS1, PIK3R2; PKCa: PRKCA)

\section{Determination of genetic effects of exposure to waveband combinations}

As it is observed that wavebands (i.e. 50 and $10 \mathrm{~nm}$ ) are capable of shifting the gene expression profiles of Xiphophorus skin, we wished to determine if one waveband exposure may offset and/or further modulate the genetic effect of a different waveband, or if combining two waveband exposures may result in a completely new genetic effect, due to combined effects of both wavebands. As an initial test, we selected two waveband regions, 350-360 nm and 510$520 \mathrm{~nm}$ that produce two different genetic response peaks [19], and are positioned $150 \mathrm{~nm}$ from each other in the visible spectrum. We exposed fish to either; each waveband singly (i.e. $350-360 \mathrm{~nm}$ or $510-$ $520 \mathrm{~nm}$ ), and also to dual exposures by one waveband that was immediately followed by exposure to the second waveband (e.g., 350-360 nm and immediately followed by exposure to $510-520 \mathrm{~nm})$. In Fig. 7 panel a, we show results of $X$. maculatus exposed to 510$520 \mathrm{~nm}$ of light singly, compared to $X$. maculatus exposed to $510-520 \mathrm{~nm}$ followed immediately by exposure to 350-360 nm light. When first exposed to 510$520 \mathrm{~nm}$ and then followed by the 350-360 nm waveband, a dominant effect of the longer waveband (i.e., 510-520 nm) is observed. The dual exposed skin shows modulation of gene expression in some of the same and many different genes, but overall reflects a similar overall functional class response as the singly exposed 510-520 nm fish skin. Of the functional categories effected, by modulated regulators and gene sets, only apoptosis is predicted to be oppositely modulated (up-orange, following 510-520 nm single exposure, and down-blue following the dual exposure).

In contrast, when the order of light exposure is reversed (Fig. 7 panel b), wherein 350-360 nm exposure is immediately followed by $510-520 \mathrm{~nm}$ exposure, only four upstream regulators are shared with the singly exposed $510-520 \mathrm{~nm}$ fish skin. These four upstream regulators are all modulated in the same direction, while the combined transcriptional effects with the other regulators modulated in the 350-360 nm/510-520 nm dual exposure are predicted to result in a directional change in functional response.

As shown in Fig. 7 panel b, there is only one common regulator of the dual exposed skin that mirrors 


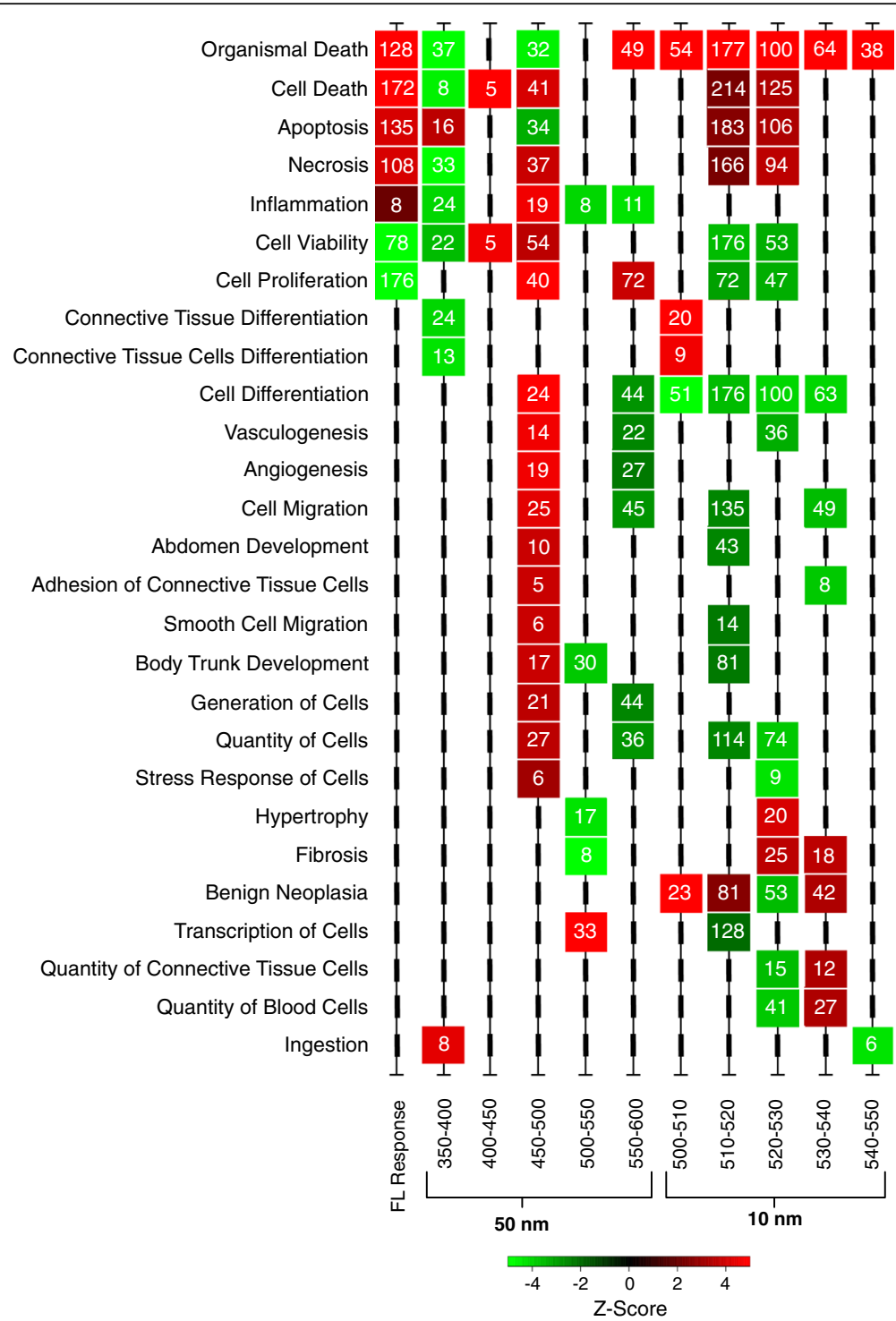

Fig. 6 A compilation of oppositely modulated functional classes (z-score $\geq|2|$; minimum of five genes) were compared through the wavebands using IPA software and plotted. Heat map color represents IPA classified z-score (red is up and green is down) and the number inside each box represents the number of genes contributing to the functional effect. Functional classes had to be oppositely modulated in at least one waveband or FL exposed samples to be plotted. For complete gene lists of each functional class see Additional file 5: Table S5a-k

the 350-360 nm singly exposed skin, apoptosis. All other principal functional categories appear to be oppositely modulated (e.g., cell proliferation and inflammation), compared to single $350-360 \mathrm{~nm}$ exposure. Thus, not only is the dual exposed skin exhibiting predicted opposite functional modulation compared to the $350-360 \mathrm{~nm}$ single waveband exposure, but also when compared to the dual exposed $510-520 \mathrm{~nm}$ followed by $350-360 \mathrm{~nm}$ skin (Fig. 7 panel a). Based on these results it appears the longer waveband (510$520 \mathrm{~nm}$ ) exerts a dominant effect on the capacity of the lower wavelength $(350-360 \mathrm{~nm})$ to modulate transcription in Xiphophorus skin.

\section{Validation of RNA-Seq determined transcriptional responses after waveband exposures}

To confirm RNA-Seq determined gene expression changes for FL and waveband light exposures, we employed an independent platform, the NanoString nCounter ${ }^{\circ}$, for direct assessment of gene expression. The nCounter ${ }^{\circ}$ platform works as a simultaneous gene expression detection system for many transcripts [21-24]. The technology employs oligonucleotide capture and reporter sequences complementary to each target gene [21]. We have developed and utilized $[15,19,20]$ a Xiphophorus 200 gene target light responsive NanoString panel and used this to determine transcriptional 


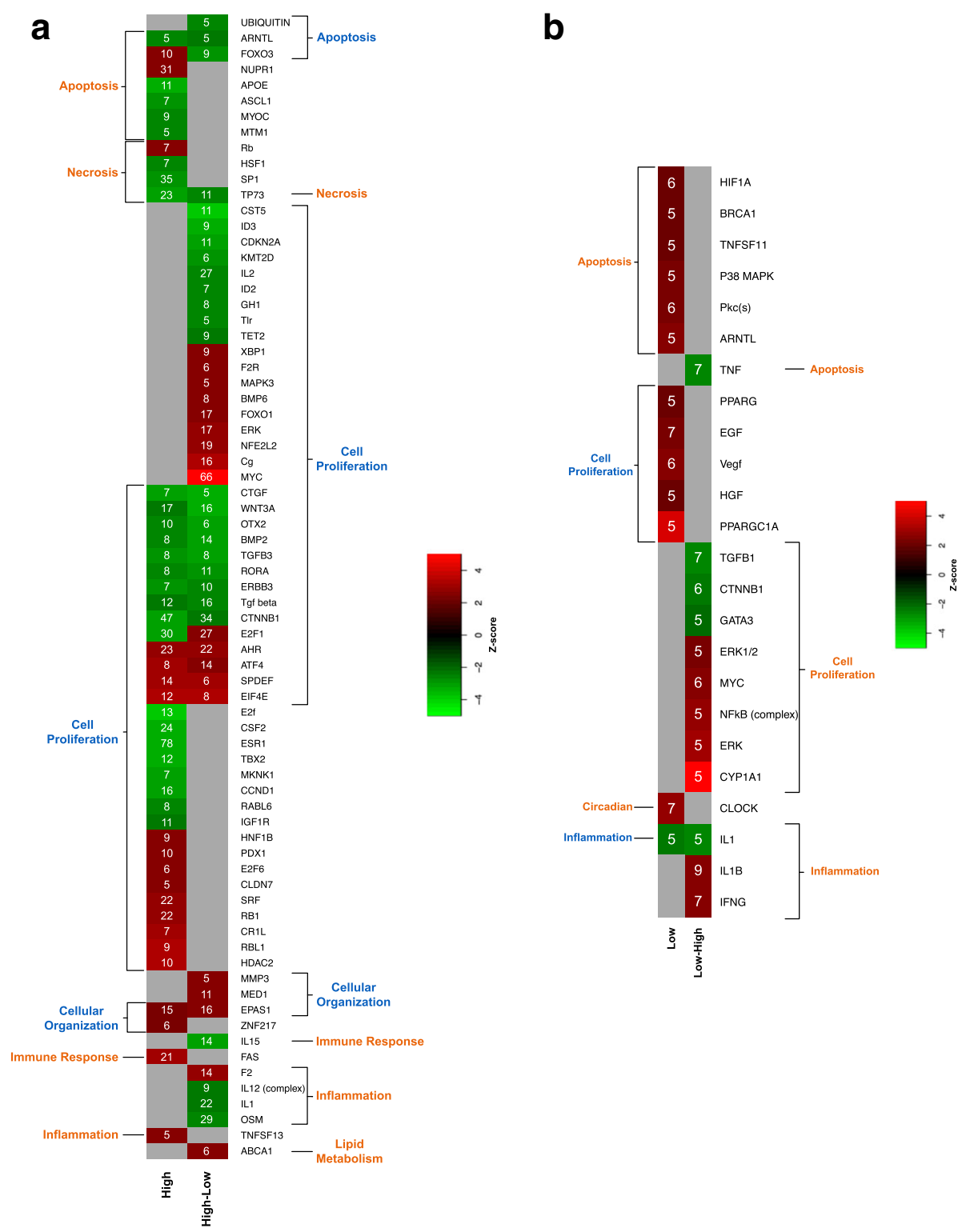

Fig. 7 Panel (a) Results from X. maculatus skin after exposure to 510-520 nm (High) of light, or 510-520 nm of light immediately followed by exposure to 350-360 nm of light. When exposed first to $510 \mathrm{~nm}$ of light and then $350 \mathrm{~nm}$ of light (High-Low) the effect observed mimics the solely exposed $510-520 \mathrm{~nm}$ waveband results where 18 upstream regulators are shared by the two exposure types. Dominate functions effected by either exposure regimen effect apoptosis, necrosis, cell proliferation, cellular organization, immune and inflammation response and lipid metabolism. Of all pathways modulated, only apoptosis is oppositely modulated; up (orange) following 510-520 nm exposure and down (blue) following the High-Low exposure. The numbers of genes showing modulated transcription in each functional pathway are indicated by the number inside of each red (up-modulated) and green (down-modulated) box. For complete gene lists of each upstream regulator see Additional file 6: Table S6a-d. Panel (b) X. maculatus exposed to 350-360 nm (Low) of light compared to X. maculatus exposed to 350-360 nm of light immediately followed by exposure to 510-520 nm (Low-High) of light. When exposed first to $350 \mathrm{~nm}$ of light and then $510 \mathrm{~nm}$ of light, the observed effects are quite different from the inverse "High-Low" exposure. In this case many fewer functional classes are effected, consistent with results from single exposure of 350-360 nm vs, 510-520 nm exposure. However, of the four upstream classes effected all are oppositely regulated by the Low-High exposure, compared to the 350-360 nm exposure except apoptosis. Apoptosis is up regulated by either 350-360 nm or the Low-High exposure regimen. Not only are the main functional groups oppositely modulated in the Low-High exposure, when compared to the 350-360 nm waveband, but also when compared to the High-Low exposure (510 followed by $350 \mathrm{~nm}$, left). This suggests that although the light effect is largely muted, it is dominated by a unique set of gene regulators that oppositely effect the downstream cellular and metabolic functions. For complete gene lists of each upstream regulator see Additional file 6: Table S6a-d 
modulation after the various light exposures presented herein. Additional file 3: Table S3 presents the Xiphophorus gene targets and capture probes employed in these analyses (also see, http://www.xiphophorus.txstate.edu/NanoString). For gene expression analyses, this panel also contains 10 housekeeper genes that have been extensively tested and shown to exhibit unmodulated expression upon light exposures and within various tumor types. These 10 housekeepers represent three statistical categories (high, medium, low gene expression) and are utilized for normalization.

In Fig. 8 we present plots indicating $\log _{2}$ (Fold Change) values determined by each independent technology, RNA-Seq or NanoString. In Fig. 8, panel a, each $50 \mathrm{~nm}$ waveband exposure is plotted independently. Analysis of the $350-400 \mathrm{~nm}$ region (50 transcripts) is in orange, the $400-450 \mathrm{~nm}$ region (22 transcripts) is in gray, the 450 $500 \mathrm{~nm}$ region (19 transcripts) is in yellow, the 500$550 \mathrm{~nm}$ region (59 transcripts) is in light blue and the $550-600 \mathrm{~nm}$ region (26 transcripts) is in green. $\mathrm{R}^{2}$ values were calculated for each correlation and determined to be $0.84,0.88,0.90,0.81$ and 0.98 , respectively for each of the $50 \mathrm{~nm}$ regions. In addition, for the $50 \mathrm{~nm}$ waveband data, analysis of the correlation indicated that $97 \%$ of the transcripts tested across all wavebands were confirmed in direction.

In Fig. 8, panel b we show $\log _{2}$ (Fold Change) values determined by RNA-Seq or NanoString for each $10 \mathrm{~nm}$ waveband exposure plotted independently. Analysis of the $500-510 \mathrm{~nm}$ region (30 transcripts) is in dark blue, the $510-520 \mathrm{~nm}$ region (37 transcripts) is in orange, the
$520-530 \mathrm{~nm}$ region (24 transcripts) is in gray, the 530$540 \mathrm{~nm}$ region (32 transcripts) is in yellow and the 540 $550 \mathrm{~nm}$ region (23 transcripts) is in light blue. $\mathrm{R}^{2}$ values were calculated for each correlation and determined to be $0.71,0.81,0.86,0.87$ and 0.85 respectively for the $10 \mathrm{~nm}$ region. For the $10 \mathrm{~nm}$ exposures, analysis of the correlation indicated that $94 \%$ of the transcripts tested across all wavebands were confirmed in direction. Validation of the $4100 \mathrm{~K}$ FL exposure samples by NanoString analysis, and by quantitative real-time PCR have been previously reported $[15,19,20]$.

\section{Discussion}

Evolution occurred under full spectrum sunlight. Unlike artificial light, the solar spectrum produces intense irradiance across all wavebands in the visible spectrum from 400 to $700 \mathrm{~nm}$ (Fig. 1). Competition for resources under the solar spectrum led to development of the eye and other photoreceptive mechanisms that make efficient use of light as cues for biological responses. It is likely the same selective pressures that led to complex structures, such as the eye, were concurrently adapted to make genetic use of all wavelengths or wavebands within the solar spectrum. The perception of light and the mechanism by which it leads to signal transduction, in the sense of neural excitation, are topics that have been well-studied at the biophysical, cell biological, and physiological levels. In addition, the evolution of photoreceptors has been a recent subject of strong interest [3-12]. Light reception in the eye and transduction of
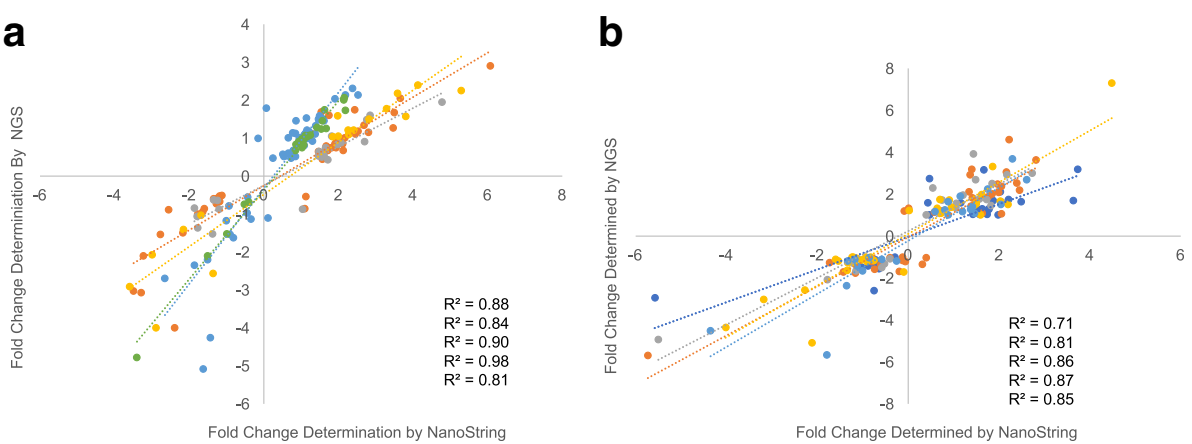

Fig. 8 To confirm RNA-Seq determined fold changes, NanoString nCounter Analysis was performed. For complete target and probe information used for confirmation see Additional file 3: Table S3. Panel (a) Log $_{2}$ (Fold Change) values for each $50 \mathrm{~nm}$ waveband exposure were determined by each independent technology and plotted. Analysis of the 350-400 nm region (50 transcripts) is in orange, the 400-450 $\mathrm{nm}$ region (22 transcripts) is in gray, the $450-500 \mathrm{~nm}$ region (19 transcripts) is in yellow, the 500-550 $\mathrm{nm}$ region (59 transcripts) is in light blue and the 550-600 $\mathrm{nm}$ region (26 transcripts) is in green. $R^{2}$ values were calculated for each correlation and determined to be $0.88,0.84,0.90,0.98$ and 0.81 respectively for each of the $50 \mathrm{~nm}$ region. In addition, analysis of the correlation indicated that $97 \%$ of the transcripts tested across all wavebands were confirmed in direction. Panel (b) To confirm RNA-Seq determined fold changes, NanoString nCounter Analysis was performed. The plot shows $\log _{2}$ (Fold Change) values determined for each $10 \mathrm{~nm}$ waveband exposure by each independent technology. Analysis of the $500-510 \mathrm{~nm}$ region (30 transcripts) is in dark blue, the $510-520 \mathrm{~nm}$ region (37 transcripts) is in orange, the $520-530 \mathrm{~nm}$ region (24 transcripts) is in gray, the $530-540 \mathrm{~nm}$ region (32 transcripts) is in yellow and the $540-550 \mathrm{~nm}$ region (23 transcripts) is in light blue. $\mathrm{R}^{2}$ values were calculated for each correlation and determined to be $0.71,0.81,0.86,0.87$ and 0.85 , respectively for the $10 \mathrm{~nm}$ region. Analysis of the correlations indicate $94 \%$ of the transcripts tested across all wavebands confirmed in the direction of modulated expression 
the photon energy into a neural impulse has been established to involve specific photoreceptor cells, rods and cones. These cells are associated with members of a very large family of proteins, termed opsins, that are finetuned to receive different wavelengths in the color spectrum. Cones are clustered into long wavelength, L cones (maxima at $\approx 560 \mathrm{~nm}$, waveband range 400 $675 \mathrm{~nm}$ ), medium wavelength, $\mathrm{M}$ cones (maxima $\approx 539 \mathrm{~nm}$, waveband range $400-650 \mathrm{~nm}$ ) and short wavelength, $\mathrm{S}$ cones (maxima $\approx 420 \mathrm{~nm}$, waveband range 325 to $524 \mathrm{~nm}$ ). The three classes of vertebrate cones differ in their absorption spectra because of differences in the amino acid sequence of the associated opsins. Therefore, it is well-established that absorption of specific wavelengths of light is utilized by animals to incite activation of a signal cascades that translate the light signal into a neural signal and a behavioral response $[4,5]$. In the brain, light signals received from hundreds of millions of rods or cones in each eye are processed, and signals for appropriate actions sent to the vertebrate organs. However, it is also recognized that among vertebrates, nonvisual mechanisms exist for photoreception, and with the exception of known role of melanopsins in circadian regulation, these are less well studied. Non-visual photoreception may be considered a master regulator of fundamental organismal biology that exerts control on both behavioral and physiological functions (e.g., circadian rhythms, cell division cycles, DNA repair, replication, etc.). Recent genomic comparative data has uncovered the presence of many more photopigments and photoreceptor molecules in vertebrates than previously thought to exist [5-7]. Conservation of these newly discovered sets of photoreception proteins among vertebrate genomes underscores non-visual photoreception as an understudied, but potentially significant, mechanism for organismal adaptation and survival.

Results presented herein depart from the wellrepresented fields of light perception that involve phototransduction, photobiology and photochemistry. Instead, our approach employed RNA-Seq to ask only about the genetic transcriptional response to light. In the detailed experiments, we utilized highly inbred $(<105$ generations) live-bearing fish of the genus Xiphophorus (http:// www.xiphophorus.txstate.edu/) to assess transcriptional changes in skin after FL or specific waveband exposures. During our experimental treatments, fish were maintained individually in $125 \mathrm{ml}$ beakers containing $100 \mathrm{ml}$ of water. The water utilized was changed at each experimental stage (i.e., pre-incubation, treatment chamber, post-exposure incubation) from the same large carboy for all fish in a particular experiment. Importantly, all control, sham and light exposed fish were carefully maintained in the exactly the same manner. Extrinsic experimental parameters that may have arisen during the overnight or post-exposure incubation periods were controlled by identically treated unexposed control, and sham treated, fish replicates. The sham treated fish replicates received identical treatment as the light exposed replicates, but with the light sources turned "off". Thus, parameters other than light exposure that may change the genetic profile would not show up in our analyses of differentially expressed genes, since they would also have been present in the unexposed control, or sham treated fish, to which all light treated fish were compared.

The 26 known species of Xiphophorus are tropical, ranging from northern Mexico, and south along the Sierra Madre uplift, into Belize and Honduras [25]. These fish are known for a variety of expressed pigment patterns and these patterns are thought to play a role in complex courting behavior necessary for live-bearing animals to select mates [26]. We employed a simple experimental protocol involving; (a) exposure to the same dose of fluorescent light $\left(4100 \mathrm{~K}, 35 \mathrm{~kJ} / \mathrm{m}^{2}\right)$, or selected wavebands of light ( $50 \mathrm{~nm}$ or $10 \mathrm{~nm}$ wavebands, $\approx 18 \mathrm{~kJ} /$ $\left.\mathrm{m}^{2}\right)$, (b) post-exposure incubation in the dark $(6 \mathrm{~h})$ to allow time for genetic remodeling, and (c) RNA-Seq transcriptional profiling to assess the genetic response incited by each selected light exposure. It is worth noting that FL lights have only been employed for $\approx 60$ years (https://energy.gov/articles/history-light-bulb) and the spectral complexity they produce is dissimilar to the solar spectrum (Fig. 1). Also, in regard to the narrow waveband exposures, the exposures performed in the detailed experiments may be the first time in history that a vertebrate animal has been subjected to, exclusively, a $50 \mathrm{~nm}$ or $10 \mathrm{~nm}$ waveband of light.

Thus, observations made in these studies imply that waveband specific genetic circuitry, whereby specific wavebands incite predictable genetic response, is embedded in the vertebrate genome. That is, specific wavebands may have been conscripted over evolutionary time for specific utility in genetic regulation. A recent paper detailing the comparative genetic responses in the skin, brain and liver, after FL exposure of three divergent fish model systems; Xiphophorus, medaka (Oryzias latipes) and zebrafish (Danio rerio) [26] supports this concept.

Given the observed post-FL modulation of transcription among gene sets involved with many varied functional classes, we attempted to de-convolute the complex FL transcriptional effects by exposure to specific $50 \mathrm{~nm}$ wavebands between 350 and $600 \mathrm{~nm}$. Here, we were able to define a small portion of the genome embedded response to each waveband, since again, no fish would have seen a $50 \mathrm{~nm}$ or $10 \mathrm{~nm}$ waveband of light until this experiment. The response of $50 \mathrm{~nm}$ waveband exposures on gene expression in Xiphophorus skin established two $50 \mathrm{~nm}$ wavebands (350-400 nm and $500-550 \mathrm{~nm}$ ) that produced significantly higher 
differential gene transcriptional modulation than the other wavebands [20]. However, in-depth analysis led to the surprising observations that each specific $50 \mathrm{~nm}$ waveband was able to selectively modulate transcription of specific gene sets and/or pathways. Indeed, exposure of the animal to $50 \mathrm{~nm}$ wavebands that are very close to each other (e.g., $350-400$ and $400-450 \mathrm{~nm}$, Fig. 4) or separated by $100 \mathrm{~nm}$ (350-400 and 450-500 nm, Fig. 6), resulted in suppression, or activation, of genes involved in the same functional classes (Figs. 4 and 6, also see Additional file 1: Table S1). These novel findings support the concept that exposure to select wavebands may be utilized to alter expression of specific genetic pathways and thereby affect the downstream genetic response of the animal to experimental protocols. Further, as noted above, the concept stemming from these studies is that one may alter the homeogenetic transcriptional state of skin and push the genetic profile toward a new position by exposure of the intact animal to specific light wavebands. Once these effects are well-documented, and better understood, it appears likely waveband specific gene expression of select pathways may become predictable, and useful as a tool in research investigations or gene or pathway specific targeted therapies.

Exposure of fish to $10 \mathrm{~nm}$ wavebands within the 500$550 \mathrm{~nm}$ region indicate the numbers of genes modulated for each light exposure is not matched to the width of the waveband, but instead each waveband has its own unique induction response that must be empirically characterized (Table 1). This may be due to slightly different total doses for each waveband (see Materials and Methods), but we feel this is unlikely since the total energy delivered did not vary appreciably among the waveband exposures between 350 and $600 \mathrm{~nm}$ (i.e., 350$400 \mathrm{~nm}\left[18.6 \mathrm{~kJ} / \mathrm{m}^{2}\right], 400-450\left[21.6 \mathrm{~kJ} / \mathrm{m}^{2}\right], 450-500$ $\left[21.2 \mathrm{~kJ} / \mathrm{m}^{2}\right], 500-550\left[17.4 \mathrm{~kJ} / \mathrm{m}^{2}\right]$ and $550-600[13$. $\left.8 \mathrm{~kJ} / \mathrm{m}^{2}\right]$ ). Further, the genetic differences between wavebands does not seem to track with differences in dose for either $50 \mathrm{~nm}$ or $10 \mathrm{~nm}$ waveband results. Thus, if specific genetic transcriptional signaling pathways have evolved to be responsive to specific wavelength regions (i.e., wavebands) of light, as suggested from the data in Figs. 4, 5 and 6, then narrower $10 \mathrm{~nm}$ waveband exposures delivered a stronger stimulus to the reception apparatus than broader $50 \mathrm{~nm}$ wavebands or the complex FL source. This may partially explain the observed general trend in higher numbers of genes transcriptionally modulated by the narrower wavebands (i.e., $10 \mathrm{~nm}$ ) compared to the $50 \mathrm{~nm}$ wavebands within shared functional classes (Fig. 4 and Additional file 1: Table S1). However, not all functional classes showed this enhanced gene representation as waveband exposure narrowed, and many exhibited completely opposite transcriptional modulation of responsive genes
(Fig. 6, Additional file 1: Table S1) as exemplified by the EGF pathway (Fig. 5).

The $10 \mathrm{~nm}$ waveband results suggest the greatest functional effects of complex FL (or 500-550 nm) exposure in skin are sequestered to $30 \mathrm{~nm}$ between 500 and $530 \mathrm{~nm}$ with a major split in functional effects between 500 and $510 \mathrm{~nm}$ (lipid metabolism) and 510-520 nm (organismal death) (Fig. 4). Additionally, the novel observations that specific pathways, such as $E G F$, may be selectively up- or down-modulated by exposure to varied wavebands of light is consistent with the differential expression observed for transcriptional expression patterns identified after complex FL exposures, where each different FL light type elicits a unique light source specific genetic response signature, in addition to shared transcriptional responses (data not shown). Given the waveband specific effects on transcriptional profiles in fish skin presented herein, and the fact that FL spectra do not reflect the complexity of sunlight (Fig. 1), an obvious question becomes: Does reduction in external light complexity have genetic consequences associated with it? Herein we only present the transcriptional effects of exposure to varied light wavebands. The degree and type(s) of effect(s) alternative lighting may, or may not, have on organismal biology is a subject for future research.

However, the innovative concept stemming from these results is that one may be able to manipulate the homeostatic genetic state of an organ, or tissue, by exposure of the intact animal to specific light wavebands. Ongoing studies using medaka (Oryzias latipes) and zebrafish (Danio rerio), to be reported elsewhere, have established that waveband specific transcriptional effects are not skin specific, but also extend to the internal organs (i.e., brain, liver). However, the mechanism(s) that have evolved that allow transduction of specific waveband signals through the organism to produce molecular genetic responses within internal organs are currently unknown.

Evolution under the solar spectrum may have segregated select genetic responses to different spectral regions (wavebands) and/or intensities. Based on gene family analyses (not shown), the observed light-driven regulatory circuits are ancient and largely conserved in the genomic circuitry of vertebrates, perhaps including mammals [26]. However, each biomedical model uniquely evolved over many millennia to their specific habitat, and therefore, would be expected to have their gene expression patterns fine-tuned to the light type and the light cycle of their environmental niche. The evolutionary fine-tuning of light-driven transcriptional regulation under a complex solar spectrum may involve both agonist and antagonistic pathway effects, that only in combination produce the proper adaptive response by the organism, as it synchronizes its behavior to the 
environmental conditions. If this is tenable, it suggests moving organisms into brightly lit FL environments, as exists in many animal facilities, may not provide the full antagonistic/agonistic signals needed for genetic calibration of the homeogenetic state. Likewise, the advent of less complex artificial lighting and concurrent extension of day length, may hallmark similar aberrant shifts in genetic homeostasis in higher mammals, including humans. Despite the very rapid culturally driven changes in light conditions, the molecular genetic response of animals to changing light types has not been studied in detail. Given the results presented herein, a prudent path for future studies may be to assess the breadth of waveband specific genetic changes among a representative set of vertebrates including mammals.

\section{Conclusions}

Changes in the transcriptional profiles of Xiphophorus maculatus skin after exposure to successive $50 \mathrm{~nm}$ wavebands of light between 350 and $600 \mathrm{~nm}$ allowed identification of waveband specific transcriptional modulation of gene sets representing discrete functional pathways within Xiphophorus skin.

Further investigation of waveband specific transcriptional modulation employing successive $10 \mathrm{~nm}$ waveband exposures within the genetically responsive 500$550 \mathrm{~nm}$ region showed; (a) greater numbers of genes may be transcriptionally modulated after $10 \mathrm{~nm}$ exposures, than observed for either $50 \mathrm{~nm}$ or FL exposures. (b) the $10 \mathrm{~nm}$ wavebands incited functional specificity, and (c) the principal genetic effects of FL are due to $30 \mathrm{~nm}$ between 500 and $530 \mathrm{~nm}$.

A large set of genetic pathways were identified exhibiting opposite transcriptional effects after different select waveband exposures.

Collectively, these results suggest one may manipulate transcription of specific genetic pathways in skin by exposure of the intact animal to select wavebands of light. We identify gene targets that may be transcriptionally modulated in a predictable manner by specific waveband exposures. Such genes, and their regulatory elements, may represent valuable tools for genetic engineering and gene therapy protocols.

\section{Methods}

\section{Fish utilized and light exposures}

All studies were approved by the Texas State University Institutional Animal Care and Use Review Board (IACUC protocol \#2015107711). Fish used in this study were maintained and utilized in accordance with the applicable OLAW guidelines governing animal experimentation in the USA, and international legislation regulations governing animal experimentation.
Xiphophorus utilized in these studies were bred and maintained in the Xiphophorus Genetic Stock Center (http://www.xiphophorus.txstate.edu/). Fish were sacrificed by over-anesthetization with MS222 (0.06\%). Fish utilized were mature male $X$. maculatus Jp $163 \mathrm{~B}, 10$ to 11 months of age, from the 105th generation of sibling inbreeding. Skin from four individual fish taken straight out of the dark cycle without any experimental treatment or handling, were utilized for RNA isolation and Illumina sequencing (controls). For each light exposure three fish were individually exposed, and RNA from the skin of these exposed fish subjected to Illumina sequencing and utilized for RNA-Seq or NanoString nCounter analysis. Prior to all light exposures, each fish was placed into an individual $125 \mathrm{~mL}$ flask filled with $100 \mathrm{~mL}$ of filtered water from their home aquaria and kept in the dark $14 \mathrm{~h}$. Fish from these individual flasks were randomly chosen for light exposure or to remain unexposed and serve as controls. Sham animals were treated as those exposed to light except the light source remained off during the sham treatment.

FL Light exposures were carried out essentially as previously detailed [19]. Briefly, FL exposure occurred in a specially designed wooden box $(77 \mathrm{~cm}$ in length, $41 \mathrm{~cm}$ in height, and $36 \mathrm{~cm}$ in depth), with a hinged wooden lid capable of sealing the interior of the box from external light. On the bottom of each of the two sides $(41 \mathrm{~cm} \times 36 \mathrm{~cm})$ were $15.5 \mathrm{~cm}$ diameter high-speed fans that maintained interior temperatures of the closed box at less than $24{ }^{\circ} \mathrm{C}$. For $\mathrm{FL}$ exposure, single fish were placed into UV transparent (UVT) plastic cuvettes $(9 \mathrm{~cm} \times 7.5 \mathrm{~cm} \times 1.5 \mathrm{~cm})$ in about $95 \mathrm{~mL}$ water and the cuvettes were suspended in a rack centered between and about $10 \mathrm{~cm}$ from the bank of four FL bulbs (each side) inside the exposure chamber. FL sources were "cool white" Philips F 20 T12/CW 20 W, Alto (i.e., $4100 \mathrm{~K} \mathrm{FL)}$ fluorescent lamps provided doses of $35 \mathrm{~kJ} / \mathrm{m}^{2}$, that equated to an exposure time of about $40 \mathrm{~min}$.

For waveband exposure of $X$. maculatus to $50 \mathrm{~nm}$ [350-400 $\left.18.6 \mathrm{~kJ} / \mathrm{m}^{2}\right), 400-450\left(21.6 \mathrm{~kJ} / \mathrm{m}^{2}\right), 450-500$ $\left(21.2 \mathrm{~kJ} / \mathrm{m}^{2}\right), 500-550\left(17.4 \mathrm{~kJ} / \mathrm{m}^{2}\right)$, and $550-600 \mathrm{~nm}$ $\left.\left(13.8 \mathrm{~kJ} / \mathrm{m}^{2}\right)\right]$ or $10 \mathrm{~nm}$ wavebands of light [500-510 (18. $\left.5 \mathrm{~kJ} / \mathrm{m}^{2}\right), 510-520\left(17.9 \mathrm{~kJ} / \mathrm{m}^{2}\right), 520-530\left(17.5 \mathrm{~kJ} / \mathrm{m}^{2}\right)$, 530-540 $\left(16.9 \mathrm{~kJ} / \mathrm{m}^{2}\right)$, and $540-550\left(16.4 \mathrm{~kJ} / \mathrm{m}^{2}\right)$, we utilized a TLS-300X Series Tunable Light Source (Newport Corporation, Irvine, CA, USA) containing an Ushio 300 W Xenon Short Arc Lamp Model 6258. Exposures were as detailed previously [20]. Briefly, light emitted from the source was passed through a Cornerstone 130 Monochromator (Newport Corporation, Irvine, CA, USA) to define specific wavelengths. The bulb was burned in $15 \mathrm{~min}$ prior to all exposure treatments. The specific wavelengths were divided by two fiber optic light cables, allowing the fish to be exposed on both sides 
simultaneously to the defined wavelengths of light. Spectral distributions were made to determine the power output of each light source at specific wavelengths using a Newport 1918-R power meter (Newport Corporation, Irvine, CA, USA). The spectral distribution of the xenon light source was measured at full spectrum $(0 \mathrm{~nm})$ using an Ocean Optics STS 350-800 nm Microspectrometer (Ocean Optics Inc., Dundedin, FL, USA) and OceanView software v1.5 (http://oceanoptics.com/product/oceanview/). The microspectrometer was calibrated to a known standard using Ocean Optics Halogen Calibrated Light Source HL-3P-CAL (Ocean Optics Inc., Dundedin, FL, USA). To cover each wavelength in each $50 \mathrm{~nm}$ region, the monochromator was set to scan and repeat (i.e. loop) using Asoftech Automation (http://www.asoftech.com/) through the wavelengths of each region $(1 \mathrm{~nm} / \mathrm{sec}$ for $50 \mathrm{~s})$ for the duration of the light exposure.

Each fish was then placed in a $4 \mathrm{~cm}$ length $\times 1 \mathrm{~cm}$ wide $\times 4.5 \mathrm{~cm}$ height quartz cuvette filled with $14 \mathrm{~mL}$ of filtered aquaria water. The cuvette was then centered between the two fiber optic light cables and covered by a cardboard box to eliminate ambient light. After exposure, the fish was removed from the cuvette, rinsed with filtered aquaria water, placed back into a $125 \mathrm{~mL}$ flask filled with $100 \mathrm{~mL}$ of filtered aquaria water, and in the dark for $6 \mathrm{~h}$ to allow for gene expression prior to sacrifice and tissue dissection.

At dissection, fish were anesthetized in an ice bath and upon loss of gill movement were sacrificed by cranial resection. Skin was dissected directly into TRI reagent (Sigma Inc., St Louis, MO, USA) and flash frozen in an ethanol dry ice bath. Remaining tissues were placed in individual $1.5 \mathrm{~mL}$ microcentrifuge tubes filled with 300 $\mu \mathrm{L}$ RNAlater (Life Technologies, Grand Island, NY, USA).

\section{RNA isolation and sequencing}

RNA isolation was performed following the Qiagen RNeasy RNA isolation protocol (Qiagen, Valencia, CA, USA). Skin samples harvested from fish were first homogenized using a hand-held homogenizer in a $1.5 \mathrm{~mL}$ microcentrifuge tube while the sample remained frozen in TRI Reagent (Sigma Inc., St Louis, MO, USA). After homogenization, $300 \mu \mathrm{L}$ of fresh $4{ }^{\circ} \mathrm{C}$ TRI Reagent was added to the samples followed by room temperature incubation for $5 \mathrm{~min}$. Chloroform extraction was performed by adding $120 \mu \mathrm{L}$ chloroform and shaken for $15 \mathrm{~s}$. Samples were centrifuged $(16,100 \mathrm{rcf}$ for $5 \mathrm{~min}$ at 4 ${ }^{\circ} \mathrm{C}$ ) for phase partition. The aqueous layer was transferred to a new $1.5 \mathrm{~mL}$ microcentrifuge tube and a second chloroform extraction performed (300 $\mu \mathrm{L}$ TRI Reagent, $60 \mu \mathrm{L}$ chloroform). After extraction, nucleic acids in the aqueous phase were precipitated with 500 $\mu \mathrm{L} 70 \% \mathrm{EtOH}$ in diethylpyrocarbonate (DEPC) treated water. The sample was then transferred to a Qiagen RNeasy mini spin column and on-column DNase treatment was performed for $15 \mathrm{~min}$ at $25^{\circ} \mathrm{C}$. RNA samples were then washed and eluted in $100 \mu \mathrm{L}$ RNase free water. RNA concentration was measured with a Qubit 2. 0 fluorometer (Life Technologies, Grand Island, NY, USA). To further assess the RNA quality, a RNA integrity (RIN) score was determined using an Agilent 2100 Bioanalyzer (Agilent Technologies, Santa Clara, CA, USA). All samples processed for RNA sequencing had a RIN score above 8 .

All RNA-seq experiments were performed, independently, on at least, two individual fish. Organs utilized for RNA-seq were from independent animals representing two exposure replicates for each light type. Isolated RNA samples were sent to Beckman Coulter Genomics (Beckman Coulter, Inc., Atlanta, GA) for Illumina Highthroughput Sequencing using the Illumina TruSeq mRNA Library Prep Kit on the HiSeq 2000 platform (Illumina, Inc., San Diego, CA, USA). RNA was sequenced (125 bp, paired-end [PE] reads) and the raw reads were trimmed and filtered using a custom Perl script and adapter sequences were removed from the sequencing reads [27]. The reads were truncated based on similarity to library adaptor sequences using custom Perl scripts [27]. Then, low-scoring sections of each read were removed, preserving the longest remaining fragment as previously described $[15,19,20]$. FastQC was then used to assess the quality of the filtered reads to identify any potential deficiencies within the data for each sample (http://www.bioinformatics.babraham.ac.uk/ projects/fastqc/).

\section{Differentially Expressed Gene (DEG) analysis}

Genes exhibiting modulated transcriptional expression due to light type or waveband exposures were identified as detailed previously [16-20]. Briefly, the trimmed and filtered reads are mapped to the Xiphophorus cDNA reference sequences (Ensembl) [28] using GSNAP [29]. Mapped reads are quantified as raw counts in each file by xEpress. Differentially expressed genes were analyzed using the R-Bioconductor package edgeR [30]. For a gene to be a Differentially Expressed Gene (DEG), it has to alter at least two fold with a False Discovery Rate (FDR) adjusted $p$-value less than $0.05\left(\log _{2} \mathrm{FC} \geq 1\right.$ or $\log _{2} \mathrm{FC} \leq-1$, FDR $\left.<0.05\right)$. Two experimental replicates were utilized for DEG analyses.

Extrinsic experimental parameters that may have arisen during the overnight or post-exposure incubation periods were controlled by identically treated unexposed control, and sham treated, fish replicates. The sham treated fish replicates received identical treatment as the light exposed replicates, but with the light sources 
turned "off". Analyses of differentially expressed genes were compared between unexposed control and sham treated fish, to determine those genes altered due to the experimental protocol or handling. Genes showing differential expression in the sham samples relative to the unexposed controls (never more than $5 \%$ of the total differentially expressed genes), were removed from comparisons between the light/waveband exposed and unexposed control fish samples prior to functional analyses.

\section{Functional analysis of differentially expressed genes}

Bioinformatics analysis of exposure data was performed using Ingenuity Pathway Analysis (IPA; Qiagen, Redwood City, CA.) for clustering and assessing the biological function of differentially expressed genes, as well as, for inferring up-stream regulators aiding further mechanistic interpretation. Xiphophorus Ensemble IDs of DEGs were converted to human homolog gene IDs using Ensemble Biomart. Herein, the term "pathways" is short for canonical pathways as assigned by IPA based on input DEG data. IPA assigns DEGs to pathways if the analysis results in a DEG that has previously been identified within well-established signaling or metabolic pathways based on published literature. Pathway analysis is performed by testing the over-representation of genes belonging to a certain pathway in the input DEGs. Pathways with an enrichment $-\log _{10}(p$-value) score $>1.3(p$ value $<0.05)$ were kept for further analysis. To predict overall pathway activation or repression, a z-score is calculated by comparing observed differential gene expression and expected gene expression directions. $\mathrm{z}$-score $\geq 2$ is used to determine a pathway that is activated, and a $\mathrm{z}-$ score $\leq-2$ is used to determine a pathway that is repressed.

\section{NanoString validation of RNA-Seq}

To validate these data, we employed the NanoString nCounter ${ }^{\circ}$ platform. The nCounter ${ }^{\circ}$ platform works as a simultaneous gene expression detection system for hundreds of transcripts [21-24]. The technology employs oligonucleotide capture and reporter sequences complementary to each selected light responsive gene, determined from our previous studies, in order to validate modulated genes in the FL, 50 and $10 \mathrm{~nm}$ waveband exposures [21]. A custom 200 Xiphophorus gene target NanoString panel was utilized to assess the informative gene targets shown in Fig. 8 for each exposure. Fish mRNA is hybridized in solution to gene-specific 'capture' and 'reporter' probes to form ternary complexes. After hybridization, biotin-labeled capture probes anchor ternary complexes to a slide. Reporter probes may contain $4^{7}(16,384)$ different fluorescent barcode combinations. Scanning barcoded, immobilized, and electrophoresis extended complexes decodes each hybrid complex to directly count mRNAs without nucleic acid amplification. The gene targets analyzed in this work by NanoString are presented in Additional file 3: Table S3. The raw read counts generated from different nCounter slots were first normalized to built-in positive controls to remove effect of hybridization efficiency differences. Subsequently, the normalized read counts were scaled to the geometric mean of housekeeping genes to remove effect of different amount of RNA loaded into different slots and background noise removed from read counts. Differential expression was assessed by calculating gene expression fold change between light exposed samples to controls.

\section{Additional files}

Additional file 1: Table S1. Functional classes determined by IPA were compared for each 50 and $10 \mathrm{~nm}$ waveband (z-score $\geq|2|, 5$ gene minimum). Unique classes are those that only appear in that waveband and are not shared with any other waveband. Opposite classes are functional classes that were predicted to be up-modulated in one waveband and down modulated in another waveband. A list of all Functional classes predicted by IPA can be found in Additional file 2: Table S2a-k. This table compares and reports both within 50 and $10 \mathrm{~nm}$ regions and between 50 and $10 \mathrm{~nm}$ regions. (PDF $21 \mathrm{~kb}$ )

Additional file 2: Table S2a-k. A list of all differentially modulated genes used by IPA enrichment software to predict the direction of change for each functional class represented in Additional file 1: Table S1. Table $\mathrm{a}$ is $\mathrm{FL}$, tables $\mathrm{b}-\mathrm{e}$ are the $50 \mathrm{~nm}$ wavebands and tables $\mathrm{g}-\mathrm{k}$ are the $10 \mathrm{~nm}$ wavebands. (ZIP $701 \mathrm{~kb}$ )

Additional file 3: Table S3. A complete list of all NanoString targets and probe sequences used to verify the RNA-Seq data for each waveband exposure. (ZIP $242 \mathrm{~kb}$ )

Additional file 4: Table S4a-k. A list of all differentially modulated genes used by IPA enrichment software to predict the direction of change for each functional class represented in Fig. 4. Table a is FL, tables b-e are the $50 \mathrm{~nm}$ wavebands and tables $\mathrm{g}-\mathrm{k}$ are the $10 \mathrm{~nm}$ wavebands. (ZIP $262 \mathrm{~kb}$ )

Additional file 5: Table S5a-k. A list of all differentially modulated genes used by IPA enrichment software to predict the direction of change for each functional class represented in Fig. 6. Table a is FL, tables $\mathrm{b}$-e are the $50 \mathrm{~nm}$ wavebands and tables $\mathrm{g}-\mathrm{k}$ are the $10 \mathrm{~nm}$ wavebands. (ZIP $77 \mathrm{~kb}$ )

Additional file 6: Table S6a-d. A list of all differentially modulated genes used by IPA enrichment software to predict the direction of change for each upstream regulator represented in Fig. 7. Table a is the list for the low waveband exposure, table $b$ is for the low-high exposure, table $\mathrm{c}$ is the high exposure and table $\mathrm{d}$ is the high-low exposure. (PDF $28 \mathrm{~kb})$

\section{Abbreviations}

DNA: Deoxyribonucleic acid; EGF: Epidermal growth factor; FC: Fold change; Fdr: False discovery rate; FL: $4100 \mathrm{~K}$ fluorescent light, commercially termed "cool-white" fluorescent light; HUGO id: Human gene nomenclature; IPA: Ingenuity Pathway Analysis (IPA; Qiagen, Redwood City, CA.); kJ/ $\mathrm{m}^{2}$ : kilojoules per square meter; Nm: nanometer; RNA: Ribonucleic acid; RNASeq: A technique that uses high-throughput next generation sequencing to reveal the presence and quantity of RNA in a biological sample at a given moment in time; UVA or UVB: Ultraviolet light in the A $(315-400 \mathrm{~nm})$ or B (280-315 nm) regions.; Waveband: A $50 \mathrm{~nm}$ region of the solar spectrum 
between 350 and $600 \mathrm{~nm}$ (i.e., 350-400 nm, 400-450 nm, etc.), or a $10 \mathrm{~nm}$ region of the solar spectrum between 500 and $550 \mathrm{~nm}$ (i.e., $500-510 \mathrm{~nm}$, 510-520 nm, etc.)

\section{Acknowledgements}

The authors would like to thank the staff of the Xiphophorus Genetic Stock Center, Texas State University, for maintaining the pedigreed fish lines and caring for the animals used in this study.

\section{Funding}

Support for this project was provided in part by the NIH, ORIP grants R24

OD-011120, R24-OD-011199, R24-OD-018555, and Texas State University.

\section{Availability of data and materials}

All RNA-Seq short read sequence data utilized to prepare the differential expression analyses presented herein are deposited in the Gene Expression Omnibus (GEO), accession number is GES112473 (https://www.ncbi.nlm.nih.gov/geo/query/acc.cgi?acc=GSE112473).

\section{Authors' contributions}

RBW is the principal investigator who conceived of the project, designed the research and wrote the overall manuscript. $Y L, M B, R S$, contributed to writing sections and critical editing of the paper. JC, KN, SMW, DJW, WB, MS performed the animal exposures, dissections and RNA isolations. $Y L, M B, W B$ performed bioinformatic analyses, $Y L, M B, W B$ contributed to functional clustering data analyses and developed the figures, $\mathrm{YL}, \mathrm{MB}, \mathrm{WB}$ performed NanoString validation studies. All authors have read and approved this manuscript.

\section{Ethics approval}

All animal studies were approved by the Texas State University Institutional Animal Care and Use Review Board (IACUC protocol \#2015107711). All fish used in this study were from aquaria housed stock and were kept and sampled in accordance with the applicable national and international legislation regulations governing animal experimentation. Only fish, Xiphophorus maculatus Jp 163 B were utilized in these studies. These animals were bred and maintained in the Xiphophorus Genetic Stock Center (http://www.xiphophorus.txstate.edu/), a scientific animal resource facility supported by the National Institutes of Health. The fish utilized were raised from laboratory stocks and maintained in accordance with the applicable OLAW guidelines governing animal experimentation in the USA.

\section{Consent for publication}

This research does not involve human subjects, human material, or human data.

\section{Competing interests}

The authors declare that they have no competing interests.

\section{Publisher's Note}

Springer Nature remains neutral with regard to jurisdictional claims in published maps and institutional affiliations.

\section{Received: 5 December 2017 Accepted: 26 April 2018}

\section{Published online: 10 May 2018}

\section{References}

1. Pahlberg J, Sampath AP. Visual threshold is set by linear and nonlinear mechanisms in the retina that mitigate noise. BioEssays. 2011;33(6):438-47.

2. Nakane N, Yoshimura T. Universality and diversity in the signal transduction pathway that regulates seasonal reproduction in vertebrates. Front Neurosci. 2014:8(115):1-7.

3. Brzezinski JA, Reh TA. Photoreceptor cell fate specification in vertebrates. Comp Biologists. 2015;142:32263-3273.

4. Kennis JT, Mathes T. Molecular eyes: proteins that transform light into biological information. Interface Focus. 2013;3:20130005. https://doi.org/10. 1098/rsfs.2013.0005. Royal Society Publishing

5. Porter ML, Blasic JR, Bok MJ, Cameron EG, Pringle T, Cronin TW, Robinson PR. Shedding new light on opsin evolution. Proc R Soc B. 2011;279:3-14.
6. Davies WI, Tami TK, Zheng L, Fu JK, Rihel J, Foster RG, Whitmore D, Hankins MK. An extended family of novel vertebrate photopigments is widely expressed and displays a diversity of function. Genome Res. 2015;25:1666-79.

7. Davies WI, Collin SP, Hunt DM. Molecular ecology and adaptation of visual photopigments in craniates. Mol Ecol. 2012;21:3121-58.

8. Wagner $\mathrm{H}-\mathrm{J}$, Kroger $\mathrm{RH}$. Adaptive plasticity during the development of colour vision. Prog Retin Eye Res. 2005;24:521-36.

9. Hunt DM, Hankins MW, Collin SP, Justin Marshall N, editors. Evolution of visual and non-visual pigments: volume 4 of Springer series in vision research. New York: Springer; 2014. p. 276. ISBN: 978-1-4614-4354-1

10. Kojima D, Fukada Y. Non-visual photoreception by a variety of vertebrate opsins. Novartis Found Symp. 1999;224:265-79.

11. Peirson SN, Halford S, Foster RG. The evolution of irradiance detection: melanopsin and the non-visual opsins. Philos Trans R Soc Lond B Biol Sci. 2009:364:2849-65.

12. Whitmore D, Foulkes NS, Sassone-Corsi P. Light acts directly on organs and cells in culture to set the vertebrate circadian clock. Nature. 2000:404:87-91.

13. Meyer A, Van de Per Y. From $2 R$ to $3 R$ : evidence for a fish specific genome duplication (FSGD). BioEssays. 2005;27(9):937-45.

14. Hoegg S, Brinkman H, Taylor JS, Meyer A. Phylogenetic timing of the fishspecific genome duplication correlates with the diversification of teleost fish. J Molec Evol. 2004;59:190-203.

15. Yang K, Boswell M, Walter DJ, Downs K, Gaston-Pravia K, Garcia T, Shen Y, Mitchell DL, Walter RB. UVB-induced gene expression in the skin of Xiphophorus maculatus Jp163 B. Comp Biochem Physiol C. 2014;163:86-94.

16. Lu Y, Boswell M, Boswell B, Yang K, Schartl M, Walter RB. Molecular genetic response of $X$. maculatus - $X$. couchianus interspecies hybrid skin to UVB exposure. Comp Biochem Physiol C. 2015;178:86-92.

17. Boswell W, Boswell M, Titus J, Riojas A, Lu Y, Shen J-J, Walter RB. Sex specific molecular genetic response to UVB exposure in Xiphophorus maculatus skin. Comp Biochem Physiol C. 2015;178:76-85.

18. Walter DJ, Boswell M, Volk de García S, Walter SM, Breitenfeldt EW, Boswell W, Walter RB. Characterization and differential expression of DNA photolyases in Xiphophorus. Comp Biochem Physiol C. 2014;163:77-85.

19. Walter RB, Walter DJ, Boswell WT, Caballero KL, Boswell M, Lu Y, Chang C, Savage M. Exposure to fluorescent light triggers down regulation of genes involved with mitotic progression in Xiphophorus skin. Comp Biochem Physiol C. 2015:178:93-103.

20. Chang J, Boswell WT, Boswell M, Caballero KL, Lu Y, Walter RB. Molecular genetic response in Xiphophorus maculatus skin to varying wavelengths of light. Comp Biochem Physiology C. 2015;178:104-15.

21. Gat-Viks I, Chevrier N, Wilentzik R, Eisenhaure T, Raychowdhury Y, Steuerman Y, Shalek AK, Hacohen N, Amit I, Regev A. Deciphering molecular circuits from genetic variation underlying transcriptional responsiveness to stimuli. Nat Biotechnol. 2013;31(4):342-9.

22. Hudson RS, Yi M, Volfovsky N, Prueitt RL, Esposito D, Volinia S, Liu CG, Schetter AJ, Van Roosbroeck K, Stephens RM, Calin GA, Croce CM, Ambs S. Transcription signatures encoded by ultraconserved genomic regions in human prostate cancer. Mol Cancer. 2013:12:13.

23. Jeselsohn RM, Werner $L$, Regan MM, Fatima A, Gilmore L, Collins LC, Beck AH, Bailey ST, He HH, Buchwalter G, Brown M, Iglehart JD, Richardson A Come SE. Digital quantification of gene expression in sequential breast cancer biopsies reveals activation of an immune response. PLoS One. 2013; 8(5):e64225

24. Geiss GK, Bumgarner RE, Birditt B, Dahl T, Dowidar N, Dunaway DL, Dimitrov K. Direct multiplexed measurement of gene expression with color-coded probe pairs. Nature. Biotechnol. 2008;26(3):317-25.

25. Kallman KD, Kazianis S. The Genus Xiphophorus in Mexico, and Central America. Zebrafish. 2006:3:267-81.

26. Boswell M, Boswell W, Lu Y, Savage M, Mazurek Z, Chang J, Muster J, Walter $\mathrm{RB}$. The transcriptional response of skin to fluorescent light exposure in viviparous (Xiphophorus) and oviparous (Danio, Oryzias) fishes. Comp Biochem Physiol C. 2017; In Press

27. Garcia TI, Matos I, Shen Y, Pabuwal V, Coelho MM, Wakamatsu Y, Schartl M, Walter RB. Novel method for analysis of allele specific expression in triploid Oryzias latipes reveals consistent pattern of allele exclusion. PLoS One. 2014; 9(6):e100250.

28. Schartl M, Walter RB, Shen Y, Garcia T, Catchen J, Amores A, Braasch I, Chapolin D, Volff JN, Lesch KP, Bisazza A, Minx P, Wilson RK, Fuerstenberg S, Boore J, Postlethwait JH, Warren WC. The genome of the platyfish, Xiphophorus maculatus. Nat Genet. 2013;45(5):567-72. 
29. Wu TD, Nacu S. Fast and SNP-tolerant detection of complex variants and splicing in short reads. Bioinformatics. 2010;26(7):873-81.

30. Robinson MD, McCarthy DJ, Smyth GK. edgeR: a Bioconductor package for differential expression analysis of digital gene expression data.

Bioinformatics. 2010;26:139-40.

Ready to submit your research? Choose BMC and benefit from:

- fast, convenient online submission

- thorough peer review by experienced researchers in your field

- rapid publication on acceptance

- support for research data, including large and complex data types

- gold Open Access which fosters wider collaboration and increased citations

- maximum visibility for your research: over $100 \mathrm{M}$ website views per year 